\title{
i-Propylammonium Lead Chloride Based Perovskite Photocatalysts for Depolymerization of Lignin Under UV Light
}

Samia Kausar ${ }^{1}$, Ataf Ali Altaf ${ }^{1,2, *}$, Muhammad Hamayun ${ }^{1}$, Nasir Rasool ${ }^{3}$, Mahwish Hadait ${ }^{1}$, Arusa Akhtar ${ }^{1}$, Shabbir Muhammad ${ }^{4,5}{ }^{(D}$, Amin Badshah ${ }^{6}$, Syed Adnan Ali Shah ${ }^{7,8}{ }^{(D)}$ and Zainul Amiruddin Zakaria 9,10,*(D)

1 Department of Chemistry, University of Gujrat, Hafiz Hayat Campus, Gujrat 50700, Pakistan; samiakosar93@gmail.com (S.K.); hamayunf@uog.edu.pk (M.H.); atafali83@gmail.com (M.H.); arusachaudry@gmail.com (A.A.)

2 Department of Chemistry, University of Okara, Okara 56300, Pakistan

3 Department of Chemistry, Government College University, Faisalabad 38000, Pakistan; nasirrasool@gcuf.edu.pk

4 Research Center for Advanced Material Science (RCAMS), King Khalid University, P.O. Box 9004, Abha 61413, Saudi Arabia; shabbir193rb@gmail.com

5 Department of Physics, College of Science, King Khalid University, P.O. Box 9004, Abha 61413, Saudi Arabia

6 Department of Chemistry, Quaid-i-Azam University, Islamabad 45320, Pakistan; aminbadshah@qau.edu.pk

7 Faculty of Pharmacy, Universiti Teknologi MARA Cawangan Selangor Kampus Puncak Alam, Bandar Puncak Alam 42300, Selangor D. E., Malaysia; syedadnan@uitm.edu.my

8 Atta-ur-Rahman Institute for Natural Products Discovery (AuRIns), Universiti Teknologi MARA Cawangan Selangor Kampus Puncak Alam, Bandar Puncak Alam 42300, Selangor D. E., Malaysia

9 Department of Biomedical Science, Faculty of Medicine and Health Sciences, Universiti Putra Malaysia, Serdang 43400, Selangor, Malaysia

10 Halal Institute Research Institute, Universiti Putra Malaysia, Serdang 43400, Selangor, Malaysia

* Correspondence: atafali.altaf@uog.edu.pk (A.A.A.); zaz@upm.edu.my (Z.A.Z.); Tel.: +92-3325049532 (A.A.A.); +603-8947-2111 (Z.A.Z.); Fax: +603-8943-6178 (Z.A.Z.)

Academic Editor: Łukasz Klapiszewski

Received: 30 May 2020; Accepted: 22 June 2020; Published: 31 July 2020

\begin{abstract}
Lignin depolymerization for the purpose of synthesizing aromatic molecules is a growing focus of research to find alternative energy sources. In current studies, the photocatalytic depolymerization of lignin has been investigated by two new iso-propylamine-based lead chloride perovskite nanomaterials (SK9 and SK10), synthesized by the facile hydrothermal method. Characterization was done by Powder X-Ray Diffraction (PXRD), Scanning Electron Microscopy (SEM), UV-Visible (UV-Vis), Photoluminescence (PL), and Fourier-Transform Infrared (FTIR) Spectroscopy and was used for the photocatalytic depolymerization of lignin under UV light. Lignin depolymerization was monitored by taking absorption spectra and catalytic paths studied by applying kinetic models. The \%depolymerization was calculated for factors such as catalyst dose variation, initial concentration of lignin, and varying temperatures. Pseudo-second order was the best suited kinetic model, exhibiting a mechanism for lignin depolymerization that was chemically rate controlled. The activation energy $\left(E_{a}\right)$ for the depolymerization reaction was found to be $15 \mathrm{~kJ} / \mathrm{mol}$, which is remarkably less than conventional depolymerization of the lignin, i.e., $59.75 \mathrm{~kJ} / \mathrm{mol}$, exhibiting significant catalytic efficiencies of synthesized perovskites. Products of lignin depolymerization obtained after photocatalytic activity at room temperature $\left(20^{\circ} \mathrm{C}\right)$ and at $90^{\circ} \mathrm{C}$ were characterized by GC-MS analysis, indicating an increase in catalytic lignin depolymerization structural subunits into small monomeric functionalities at higher temperatures. Specifically, 2-methoxy-4-methylphenol $(39 \%)$, benzene $(17 \%)$, phenol $(10 \%)$ and catechol $(7 \%)$ were detected by GC-MS analysis of lignin depolymerization products.
\end{abstract}


Keywords: photocatalysis; lignin depolymerization; perovskites; kinetics; activation energy

\section{Introduction}

Society's dependence on non-renewable energy sources and increasing demand for fuels and chemicals are the most addressed concerns of researchers for the purpose of developing sustainable technologies that would probably enable the efficient consumption of renewable resources [1-4]. Such a striking source material is lignocellulose, which is produced in substantial quantities from agricultural and forestry activity worldwide [5]. Lignin is the major renewable energy source in nature for aromatic building blocks and has the utmost potential to produce bulk/functionalized aromatic compounds and to offer suitable alternatives to universally employed petroleum-derived BTX (benzene, toluene, and xylene) [6-8].

Lignin conversion is a potential challenge because of its high molecular weight and polymeric nature [9-11]. The quest for novel catalytic methods to transform polymeric substrates like lignin into value-added compounds initiated tremendous research in various fields, such as homogeneous catalysis [12-14] and heterogeneous catalysis [15]. Several chemical and biological pathways like thermochemical [16], oxidative [9], or biochemical [17] depolymerization methods have been investigated for the conversion of lignin to various product classes, but these are not extensively used, owing to their high operating costs [18].

Over the past ten years, light-mediated photochemistry has observed tremendous developments [19-21]. The utilization of photon energy for chemical transformations offered versatile chemical transformations, empowering numerous reactions and compounds that were previously unreachable through traditional methods over the past decade [22-24]. Hence, photocatalysis [25] is one of the advanced techniques that has applications in various fields of green energy, medicine, chemical synthesis, and environmental technology, etc., [26]. Therefore, photocatalytic depolymerization of lignin is likely to be the most environment friendly, operative, and capable method because of its productivity, energy-saving, and low cost [27].

A lot of research interest is growing in organic/inorganic hybrid alkyl lead halide perovskites $(\mathrm{RPbX} 3)$, due to their most promising catalytic, energy, and light-harvesting applications [28]. They have been widely investigated for a wide range of light-harvesting applicabilities, e.g., photovoltaics [29], light-emitting diodes (LED) or lasers [30] and radiation detection [31]. MAPbX3 solar cells have had excellent developments in efficiency in comparison to any other solar cells since their invention [32]. Metal halide-based perovskites are cost-effective materials processable in the solution, having outstanding intrinsic properties that make them appropriate candidates for light harvesting technologies in the future [33]. In particular, Pb-based hybrid perovskites have emerged as potential competitors in photovoltaics and light harvesting applications due to their high absorption coefficient, direct bandgap, long carrier lifetime, and enhanced balanced hole and electron mobility characteristics [34-36].

Various photoactive transition-metal oxides, metal oxide-based perovskites, and organic chromophores were developed to catalyze the transformations of high molecular weight substrates like lignin and have been reported previously [37-39]. However, reports on crystalline $\mathrm{RPbX3}$ for the photocatalytic transformation of high molecular weight polymeric substrates are relatively few. Metal oxide-based perovskites are being employed for lignin depolymerization, but alkyl amine-based perovskites are rarely reported for biomass conversion. Considering the importance of the subject, this study was intended to synthesize the lead chloride perovskite materials SK9 and SK10 with new alkyl moiety (iso-propylamine) for photocatalytic depolymerization of lignin not studied before. 


\section{Results and Discussion}

\subsection{Characterization}

\subsubsection{Powder X-ray Diffraction (PXRD) and Scanning Electron Microscopic (SEM) Analysis}

The phase composition and particle size of synthesized perovskite materials (SK9 and SK10) were analyzed by PXRD and the data evaluated are listed in Table 1 . Figure 1 shows Powder XRD patterns of synthesized $\mathrm{IAPbCl}_{3}$ perovskite particulates milled from a piece of corresponding large-sized crystal. The powder XRD of the crystalline $\mathrm{IAPbCl}_{3}$ perovskite material SK9 shows diffraction peaks at 22.01, 35.22, 39.34, 41.67, 51.04 $2 \theta$ values, whereas SK10 shows at 23.2, 39.4, 41.63, $51.12 \theta$ values. Observed intensities at 22-23, 35.22, 39-41 ranges of $2 \theta$ values correspond to the (100), (110), (200) lattice planes of cubic structure, most probably at room temperature [40-42]. Powder XRD analysis indicated that the crystal structure of the $\mathrm{IAPbCl}_{3}$ perovskites (SK9 and SK10) with the cubic system (space group Pm3m, $\mathrm{a}=\mathrm{b}=\mathrm{c}=5.6855 \AA$ ) at room temperature had quite similar intensities at corresponding 20 values to that reported in the literature, as given in Figure 1a-c [36].

Table 1. PXRD and SEM parameters of perovskite nanomaterials (SK9 and SK10).

\begin{tabular}{ccc}
\hline Samples & SK9 & SK10 \\
\hline & PXRD Parameters \\
\hline Average Crystallite Size D $(\mathrm{nm})$ & $77.10 \pm 5$ & $75.57 \pm 7$ \\
Volume V $=\mathrm{D}^{3}$ & $1,162,604$ & $1,051,104$ \\
Dislocation Density $\times 10^{-3}(\mathrm{~nm})^{-2}(\delta)$ & $1.43 \times 10^{-7}$ & $1.18 \times 10^{-7}$ \\
Microstrain $(\varepsilon)$ & 0.0017 & 0.0016 \\
\hline & SEM Parameters \\
\hline Material Nature & Shiny Crystalline & Shiny Crystalline \\
Dispersity & Homogenous & Homogenous \\
Structural Appearance & Broad Elliptical Leaflets & Broad Elliptical Leaflets \\
Color & White & White \\
\hline
\end{tabular}

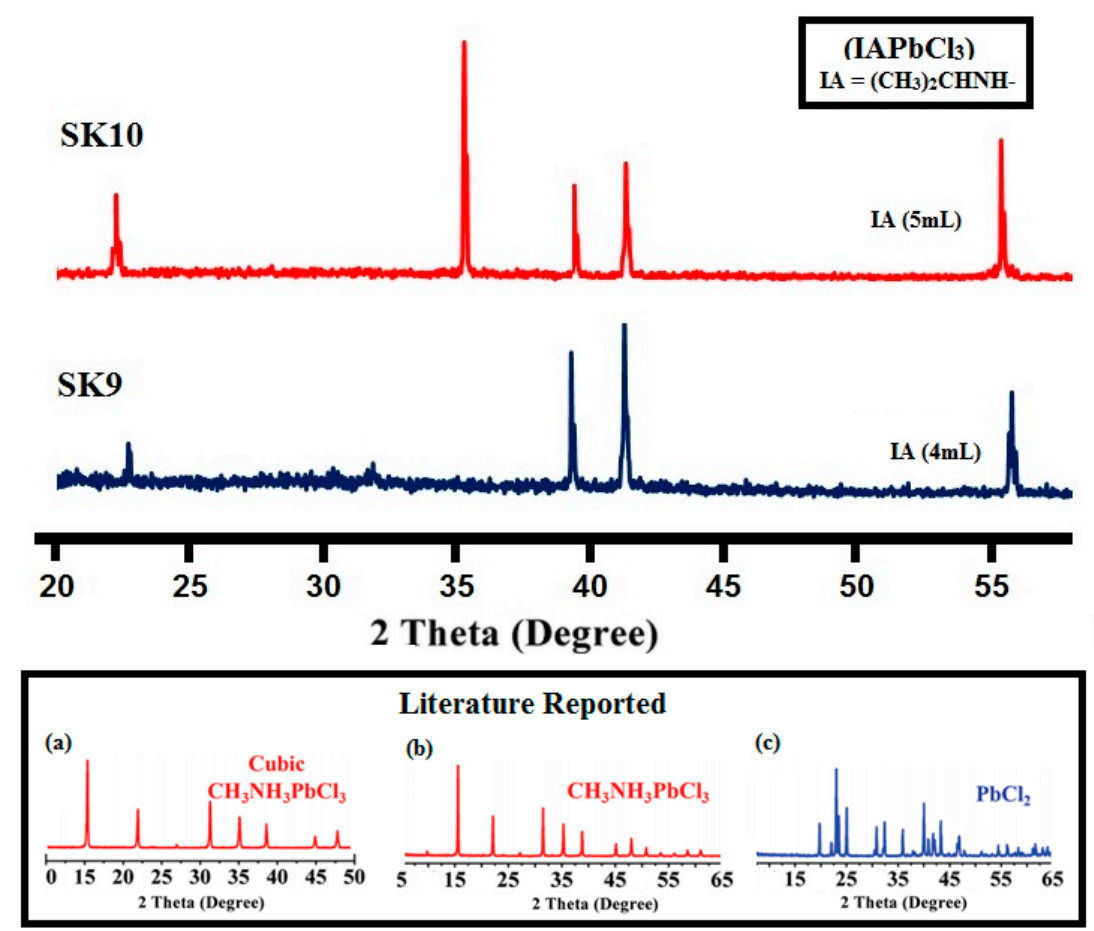

Figure 1. PXRD pattern of synthesized $\mathrm{IAPbCl}_{3}$ perovskite nanomaterials (SK9-SK10); Literature reported PXRD patterns of some methyl amine lead chloride perovskites are given in (a) and (b) and $\mathrm{PbCl}_{2}$ in (c) [36]. 
Other parameters from PXRD, i.e., crystallite size, dislocation densities, crystallite volume, and microstrain, were evaluated for SK9 and SK10, given in Table 1. Particle size calculation was performed by employing the Debye-Scherrer Equation (1) [43].

$$
\mathrm{D}=0.91 \lambda / \beta \cos \theta
$$

where $\mathrm{D}$ is the crystallite size of the material and $\lambda$ is the wavelength of the X-ray beam with $1.54 \AA$ value. The $\cos \theta$ is an angle at which diffraction occurs and $\beta$ represents the value at FWHM (full width at half maximum) [44].

The average crystallite size calculated at their corresponding intensities was found to be $77.10 \mathrm{~nm}$ for SK9 and $75.59 \mathrm{~nm}$ for SK10. The dislocation density $(\delta)$ is defined as the length of dislocation lines per unit volume of the crystal, which explains the measure of defects in the material and was calculated using the Equation (2) [45].

$$
\delta=1 / \mathrm{D}^{2}
$$

The volume of crystalline $(V)$ is measured, employing the relation $\left(\mathbf{V}=\mathbf{D}^{3}\right)$ [46], whereas the strain-induced broadening in materials because of imperfection in crystals and distortion in them is calculated as microstrain $(\varepsilon)$ [47]. Positive values of $\varepsilon$ indicate the tensile strain, whereas a negative value gives a compressive type of strain. Microstrain in synthesized perovskites was calculated following Equation (3) [47]:

$$
\varepsilon=\beta / 4 \tan \theta
$$

Very low positive values of microstrain and dislocation densities reveal the extent of defect found to be less in perovskite materials (SK9 and SK10), showing greater stability and negligible distortion or crystal imperfections.

SEM parameters calculated for perovskite nanomaterials (SK9 and SK10) are given in Table 1, whereas SEM images of SK9 and SK10 are depicted in Figure 2. Images indicated homogenous morphology incorporating very broad elliptical leaflet like structures for both materials, having somewhat rugged surface appearance. The broad elliptical structure of perovskites can play an important role in providing a greater surface for the adsorption of high molecular weight substrate for photocatalytic depolymerization.

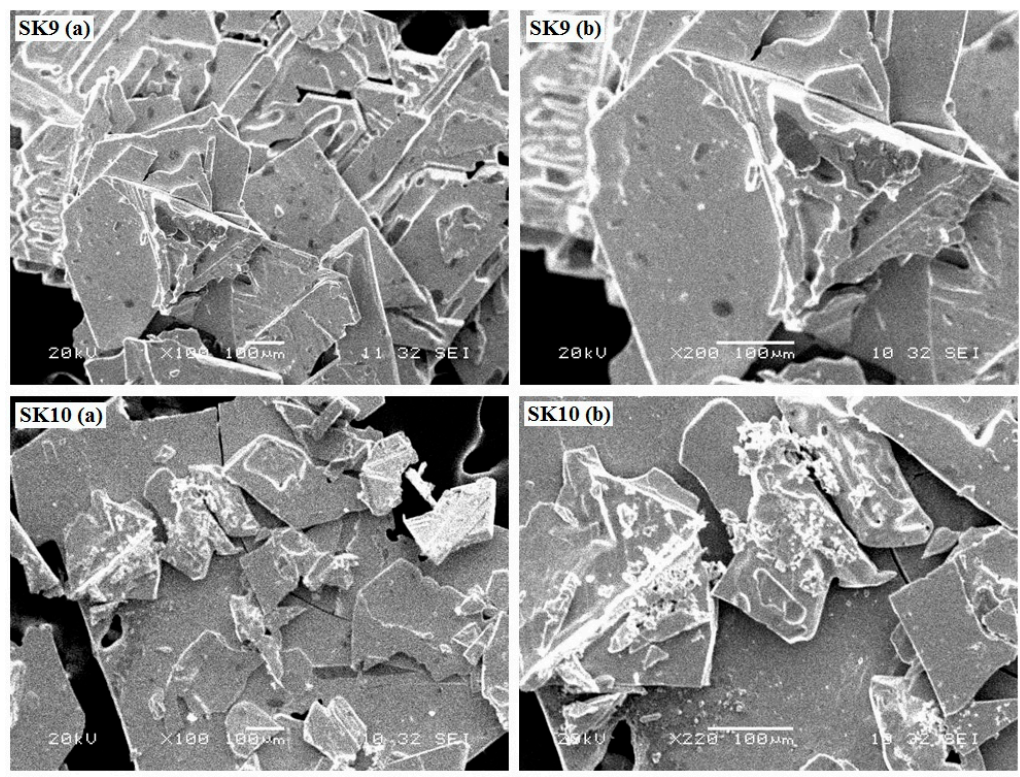

Figure 2. SEM images of synthesized perovskites SK9-SK10; [SK9 (a): With ×100 Zooming; SK9 (b): $\times 200$ Zooming; SK10 (a): With $\times 100$ Zooming; SK10 (b): $\times 220$ Zooming]. 


\subsubsection{UV and Photoluminescence (PL) Analysis}

UV-Visible spectra of perovskite nanomaterials (SK9-SK10) and $\mathrm{PbCl}_{2}$ are shown in (Figure 3). SK9 and SK10 prepared with different concentrations of iso-propyl amine (4 mL in SK9 and $5 \mathrm{~mL}$ in SK10) have shown higher absorption than $\mathrm{PbCl}_{2}$ at $209 \mathrm{~nm}$ wavelength. Extended absorption in the UV range, i.e., down to $280 \mathrm{~nm}$, signifies the interesting optical characteristics of these materials [48]. It is seen from the figure that both perovskite materials show higher absorption intensities at $209 \mathrm{~nm}$ as compared to $\mathrm{PbCl}_{2}$, whereas increasing the concentration of IA in SK10 (5 mL), there is a significant decrease in absorption peak intensity in the UV light range. High absorption intensity corresponds to using a small amount of IA (4 mL) in SK9, indicating the capability of the material to be employed in catalytic and optoelectronic applications. High absorption intensities of perovskite catalysts may play an important role for photocatalytic activities as the subject of this study is to depolymerize lignin using UV as light source.

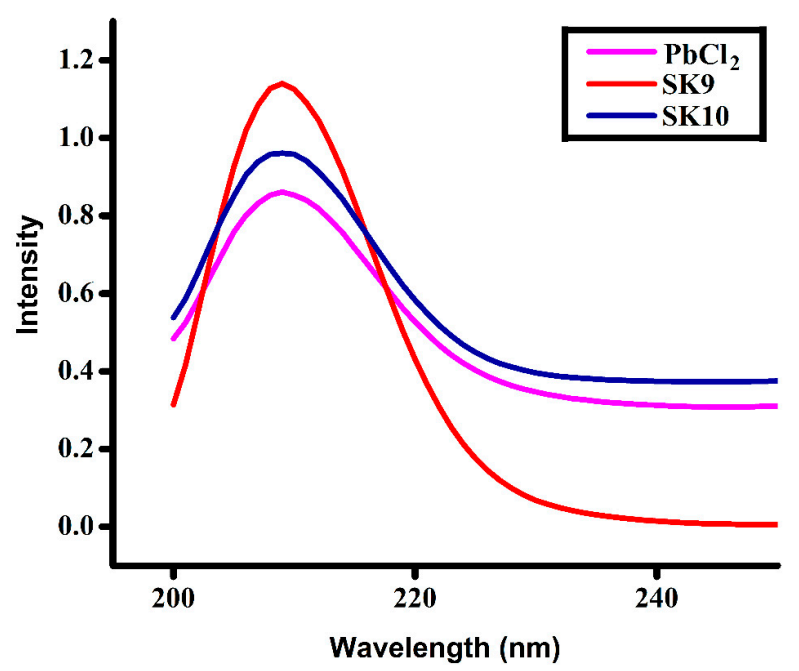

Figure 3. UV spectra of synthesized perovskites (SK9-SK10) and $\mathrm{PbCl}_{2}$.

Tauc plots for the direct bandgap have been drawn with the help of the absorption spectra of SK9 and SK10, given in Figure 4. The bandgap values were obtained through Tauc plots [49], as in Equation (4).

$$
(\alpha h v)^{2}=A\left(h v-E_{g}\right)
$$

where $\mathrm{h}$ is called Planck's constant, $v$ is frequency, $\mathrm{E}_{\mathrm{g}}$ is optical bandgap, A is the energy-independent constant. The exponent ' 2 ' explains the direct transitions, in this case, as this exponent has different values for different kinds of transitions [50]. The calculated band gap energy for SK9 and SK10 is 5.6 and $5.3 \mathrm{eV}$, respectively, which indicate that the samples can absorb light in UV to the visible region and can be utilized as efficient photocatalytic applications [50-52].

PL emission spectra of SK9 and SK10 have been obtained through a PL spectrophotometer with an exciton wavelength of $450 \mathrm{~nm}$. Figure 5 shows the PL spectra of the $\mathrm{PbCl}_{2}$ giving a sharp peak at $532 \mathrm{~nm}$, whereas synthesized perovskites SK9 and SK10 exhibiting prominent PL peaks at $469,488,532$, and $677 \mathrm{~nm}$ correspond to 2.6, 2.5, 2.3 and $1.83 \mathrm{eV}$ energy range. An increase in the emitted intensity in perovskites SK9 and SK10 in comparison to lead chloride was observed. The narrower PL peaks also designate a lower trap density in the synthesized materials, which is beneficial for them to be applied in solar cells and as efficient catalysts [53]. High emission intensities may correspond to significant photocatalytic efficiencies, as higher emissions specify low trap densities. Hence, synthesized perovskites may show excellent catalytic behaviors. 


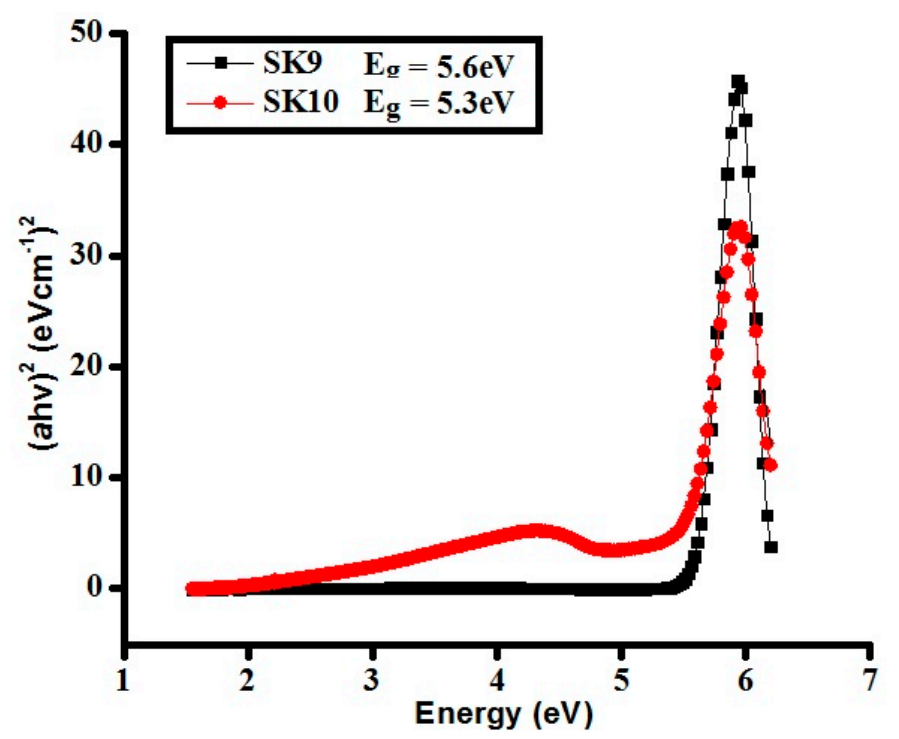

Figure 4. Tauc plots of synthesized perovskites (SK9-SK10).

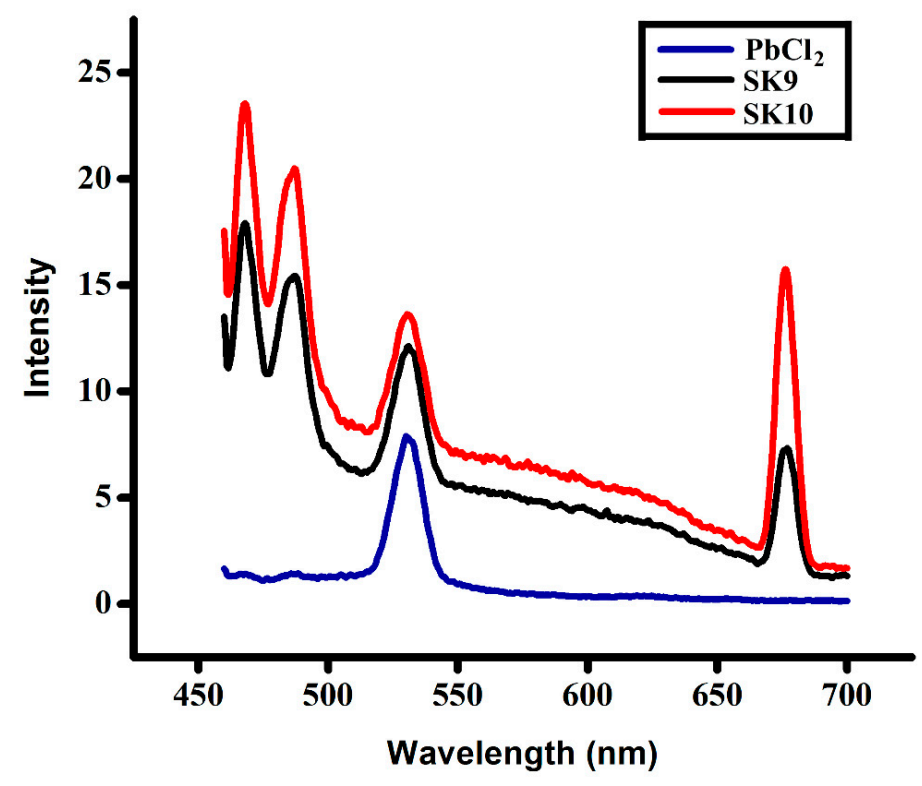

Figure 5. PL spectra of synthesized perovskites (SK9-10).

\subsubsection{FTIR Analysis}

The Fourier-Transform Infrared (FTIR) analysis of synthesized perovskites SK9 and SK10 along with $\mathrm{PbCl}_{2}$ is given in Figure 6 (some characteristic peaks are highlighted with marks in the figure). Generally, perovskite nanomaterials show absorption bands in the Raman and fingerprint region of IR due to interatomic vibrations which lie below $1000 \mathrm{~cm}^{-1}$, hence, most of the peaks in IR spectra are due to organic (iso-propylamine) moiety. Spectra showed almost similar peaks with reported methyl amine-based lead chloride perovskites [54]. The strong absorption band at the wavenumber about $3400 \mathrm{~cm}^{-1}$ is due to the presence of $\mathrm{OH}-$ in $\mathrm{PbCl}_{2}$ [55]. The small peaks at $974-980 \mathrm{~cm}^{-1}$ were originated from C-N stretching in SK9 and SK10. The intense peak near $1000 \mathrm{~cm}^{-1}$ was associated with the $\mathrm{CH}_{3}{ }^{+}$rocking vibration.

\subsection{Photocatalytic Depolymerization of Lignin Under UV Light}

For all sample aliquots taken during the photocatalytic lignin (L1) depolymerization activity at different time intervals, absorbance at $280 \mathrm{~nm}$ was measured by UV spectra. The \%lignin 
depolymerization was evaluated from the absorbance, as explained in Section 3.3. Abs 280 corresponds to the aromatic rings of lignin structure, and the decrease in it signifies the alteration of the aromatic ring structure [56].

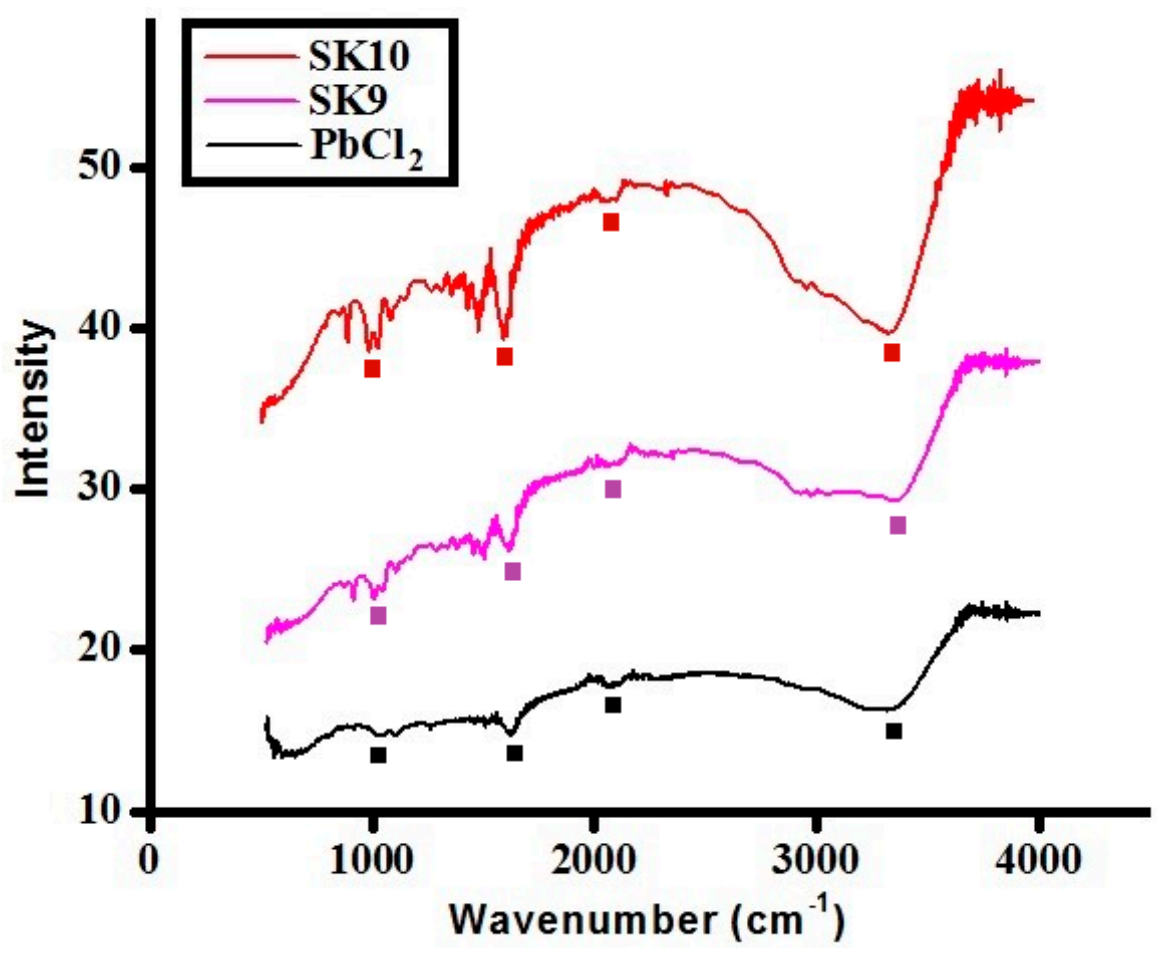

Figure 6. IR spectra of synthesized perovskites (SK9-SK10).

With the increasing photocatalytic activity time duration, the absorption peaks at $280 \mathrm{~nm}$ tend to decrease, representing the transformation of the aromatic backbone of lignin. Likewise, various factors, i.e., effect of catalytic dosage, starting lignin concentrations, and varying temperature, were studied at various time intervals by calculating \%lignin depolymerization. Perovskites exhibited high photocatalytic efficiency with an increase in \%lignin depolymerization, with increasing time intervals for all the factors studied.

\subsubsection{Effect of Time}

Lignin depolymerization was studied for SK9 and SK10 at different time intervals, i.e., 10, 20, 30, 40, 50, and $60 \mathrm{~min}$, as shown in Figure 7 and \%depolymerization was calculated, given in Table 2. SK9 and SK10 exhibited proficient catalytic efficiency to depolymerize the $0.1 \mathrm{~g} / \mathrm{L}$ lignin. After every 10 min interval of irradiation under UV light, a decrease in absorption intensity of the lignin solution was observed, as shown in Figure 7. A total of 17\% depolymerization was calculated after 10 min of UV light irradiation, which increased to 31, 48, 72, 79, 86.5\% after 20, 30, 40, 50 and 60 min, respectively, for SK9. Meanwhile, 10\% depolymerization was calculated after 10 min of UV light exposure, which increased to 20,31, 45, 65.5, 72.5\% after 20, 30, 40, 50, and $60 \mathrm{~min}$, respectively, for SK10. The proficient catalytic efficiencies of SK9 and SK10 perovskites to depolymerize lignin were credited to their larger surface areas, which provided a greater number of active sites. Correlation between the experimental data of lignin depolymerization was calculated to be very significant, as $\mathrm{R}^{2}$ values were close to 1 (Figure 8). SK9 was found more catalytically efficient than SK10, hence, other factors were studied with SK9. 

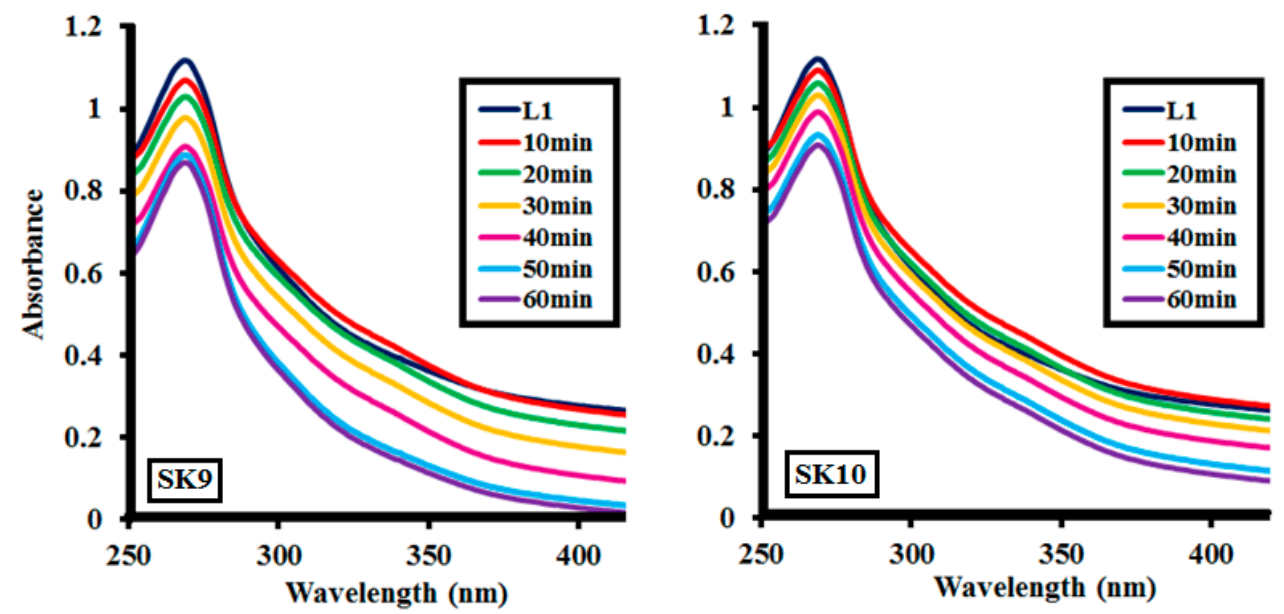

Figure 7. Photocatalytic lignin $\left(\mathbf{L 1}_{100 \mathrm{ppm}}\right)$ depolymerization by $0.1 \mathrm{~g}$ SK9 and $0.1 \mathrm{~g}$ SK10 at different time intervals.

Table 2. \%Lignin (L1 $\left.\mathbf{1}_{100 \mathrm{ppm}}\right)$ depolymerization by SK9 (0.1 g) and SK10 (0.1 g) at different time intervals.

\begin{tabular}{ccc}
\hline Time & \%Lignin $\left(\mathbf{L 1}_{\mathbf{1 0 0} \mathbf{p p m}}\right)$ Depolymerization at Different Lignin Concentrations \\
\hline $\mathbf{m i n})$ & SK9 & SK10 \\
\hline 0 & 0 & 0 \\
10 & 17 & 10 \\
20 & 31 & 20 \\
30 & 48 & 31 \\
40 & 72 & 45 \\
50 & 79 & 65.5 \\
60 & 86.5 & 72.5 \\
\hline
\end{tabular}

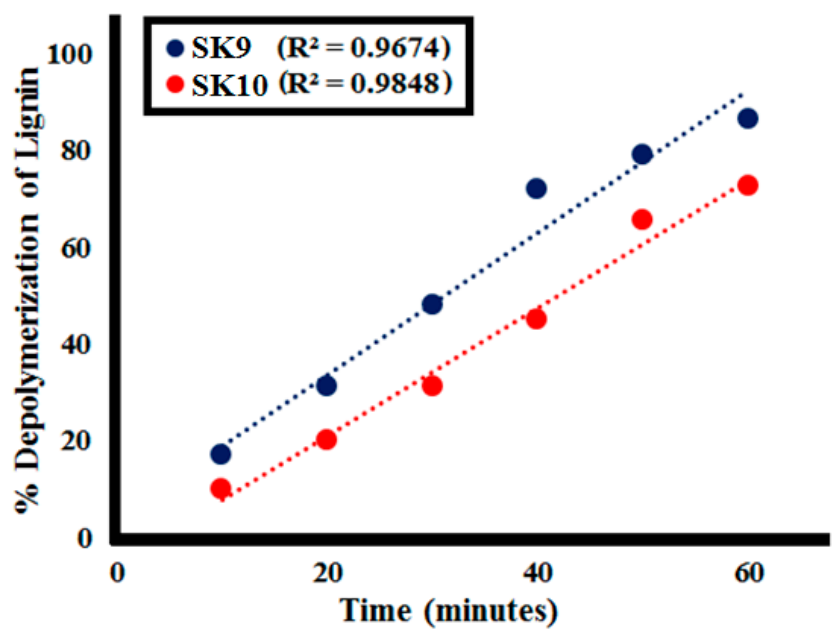

Figure 8. Correlation between the \%depolymerization of lignin $\left(\mathbf{L 1}_{100 \mathrm{ppm}}\right)$ by SK9 $(0.1 \mathrm{~g})$ and SK10 $(0.1 \mathrm{~g})$ and the time intervals.

\subsubsection{Effect of Catalyst Dosage}

Effect of the catalyst SK9 dosage on the lignin depolymerization was analyzed by variating catalyst dose from 0.025 to $0.1 \mathrm{~g} / \mathrm{L}$ for $60 \mathrm{~min}$ irradiation under UV light. After every $10 \mathrm{~min}$ interval of irradiation under UV light, a decrease in absorption intensity of the lignin solution was observed at each catalyst dosage, as shown in Figure 9. The \%depolymerization of lignin (100 ppm of L1) was calculated for different doses of SK9 at various time intervals, as given in Table 3. A decrease in absorption intensity, hence, increase in \%depolymerization, was found with increasing time intervals 
from 10 to $60 \mathrm{~min}$ for each catalyst dose, i.e., $0.025,0.05,0.075$ and $0.1 \mathrm{~g} / \mathrm{L}$ of catalyst dose, as shown in Figure S1 (supplemental data).

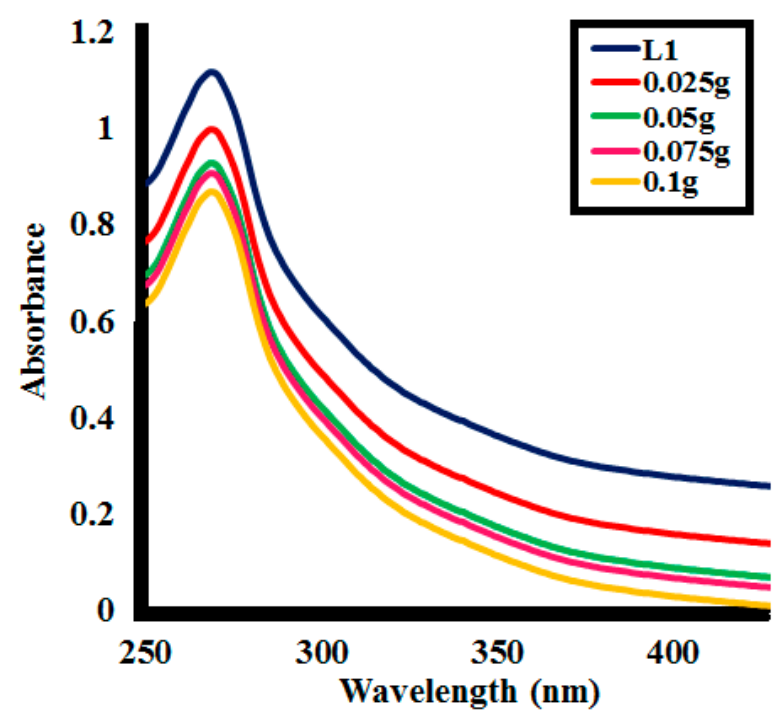

Figure 9. Photocatalytic lignin $\left(\mathbf{L 1}_{100 \mathrm{ppm}}\right)$ depolymerization by different catalyst doses of SK9 after 60 min of catalytic activity.

Table 3. \%Lignin $\left(\mathbf{L 1}_{100 \mathrm{ppm}}\right)$ depolymerization by different catalytic doses of SK9 at different time intervals.

\begin{tabular}{ccccc}
\hline Time & \multicolumn{2}{c}{ \%Lignin $\left(\mathbf{L 1}_{\mathbf{1 0 0 p p m}}\right)$ Depolymerization at Different Catalyst Doses of SK9 } \\
\hline $\mathbf{( m i n})$ & $\mathbf{0 . 0 2 5} \mathbf{g}$ & $\mathbf{0 . 0 5} \mathbf{g}$ & $\mathbf{0 . 0 7 5} \mathbf{~}$ & $\mathbf{0 . 1} \mathbf{~}$ \\
\hline 0 & 0 & 0 & 0 & 0 \\
10 & 5 & 10 & 14 & 17 \\
20 & 12 & 19 & 24 & 31 \\
30 & 22.5 & 31 & 36 & 48 \\
40 & 28 & 47 & 55.5 & 72 \\
50 & 38 & 59 & 62 & 79 \\
60 & 41.5 & 67 & 73 & 86.5 \\
\hline
\end{tabular}

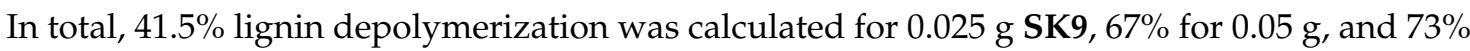
by using $0.075 \mathrm{~g}$ SK9 after $60 \mathrm{~min}$ of UV light irradiation to lignin solution. The maximum lignin depolymerization $(86.5 \%$ ) was attained at $60 \mathrm{~min}$ of UV light exposure for dosage $0.1 \mathrm{~g} / \mathrm{L}$ of SK9. A total of $17 \%$ depolymerization was calculated after $10 \mathrm{~min}$ of UV irradiation, which increased up to $31,48,72,79$, and $86.5 \%$ after 20, 30, 40, 50, and $60 \mathrm{~min}$ respectively for $0.1 \mathrm{~g}$ SK9. The maximal increase in the dose of SK9 $(0.1 \mathrm{~g} / \mathrm{L})$ resulted in maximum lignin depolymerization, most possibly because of more surface given by the catalyst, which caused a greater number of photons to interact at the catalyst's surface and increase the passage of UV irradiation through the L1 solution. The correlation between the \%lignin depolymerization and the catalyst dosage was calculated to be significant as $\mathrm{R}^{2}$ values were close to 1 (Figure 10).

\subsubsection{Effect of Initial Lignin Concentration}

The effect of starting concentrations of the lignin on its depolymerization was studied for $0.1 \mathrm{~g}$ SK9, with the lignin concentration variating from 50 to $200 \mathrm{ppm}$ and investigating the \%lignin depolymerization. After every $10 \mathrm{~min}$ interval of irradiation under UV light, a decrease in absorption intensity of the lignin solution was observed at each lignin concentration, as shown in Figure 11 (detailed in Figure S2 of supplemental data). Photocatalytic \%lignin depolymerization by SK9 was observed to decrease with the increase in lignin concentration from 50 to 200 ppm, listed in Table 4 . 
In total, 92.5\% of lignin depolymerization was achieved after 60 min of irradiation of UV light at a 50 ppm initial lignin concentration, which was decreased as 86.5\% for 100 ppm, 73\% for 150 ppm and $62.5 \%$ for 200 ppm.

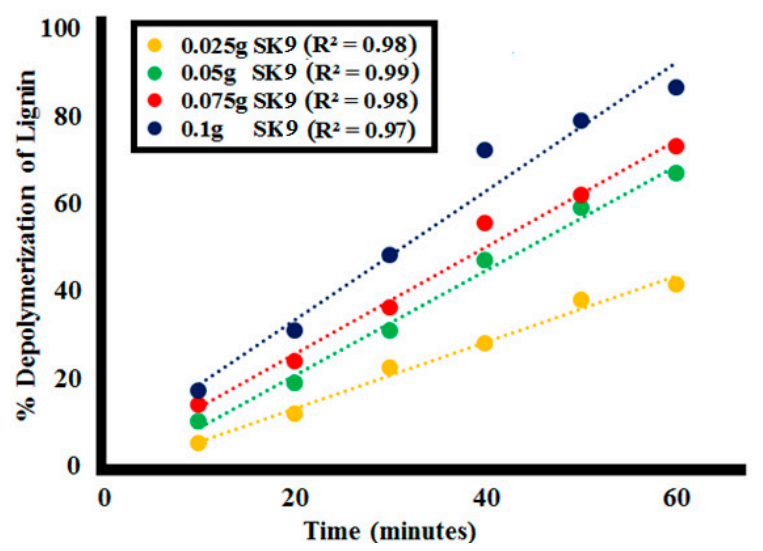

Figure 10. Correlation between \%lignin $\left(\mathbf{L 1}_{100 \mathrm{ppm}}\right)$ depolymerization by SK9 and the different catalyst doses at the different time intervals.

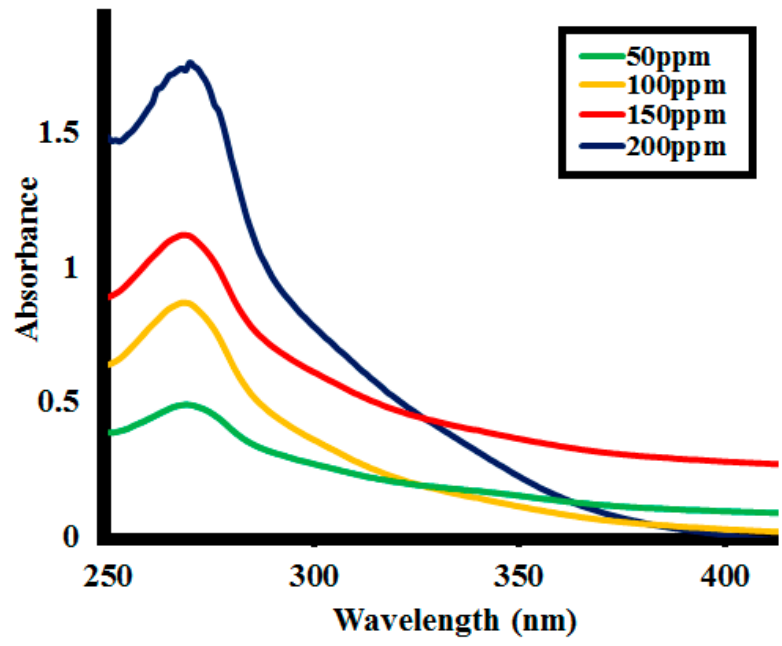

Figure 11. Photocatalytic depolymerization of the different lignin concentrations by $0.1 \mathrm{~g}$ SK9 after 60 min of catalytic activity.

Table 4. \%Depolymerization of the different lignin concentrations by SK9 (0.1 g) at the different time intervals.

\begin{tabular}{ccccc}
\hline Time & \multicolumn{4}{c}{ \%Lignin (L1) Depolymerization at the Different Lignin Concentrations } \\
\hline $\mathbf{( m i n )}$ & $\mathbf{5 0} \mathbf{p p m}$ & $\mathbf{1 0 0} \mathbf{p p m}$ & $\mathbf{1 5 0} \mathbf{p p m}$ & $\mathbf{2 0 0} \mathbf{p p m}$ \\
\hline 0 & 0 & 0 & 0 & 0 \\
10 & 15 & 17 & 7 & 8 \\
20 & 27 & 31 & 19 & 15 \\
30 & 53 & 48 & 39.5 & 23 \\
40 & 72.5 & 72 & 56 & 43 \\
50 & 81 & 79 & 67 & 59 \\
60 & 92.5 & 86.5 & 73 & 62.5 \\
\hline
\end{tabular}

The lower efficiency observed going towards high lignin concentration is possibly ascribed to the greater number of lignin molecules adsorbed on the catalyst's surface. Adsorption of the number of molecules caused a significant decrease in the availability of active sites on the catalyst's surface, hence, a smaller number of active species generated. Besides this, increasing lignin concentration resulted 
in a significant decrease in the number of photons reaching the catalyst's surface. This caused less UV light availability to excite the particles of the catalyst due to significant absorption by the lignin molecules. The correlation constant $\mathrm{R}^{2}$ between the \%depolymerization of the lignin concentrations by SK9 at the different time intervals was calculated to be close to 1, as given in Figure 12.

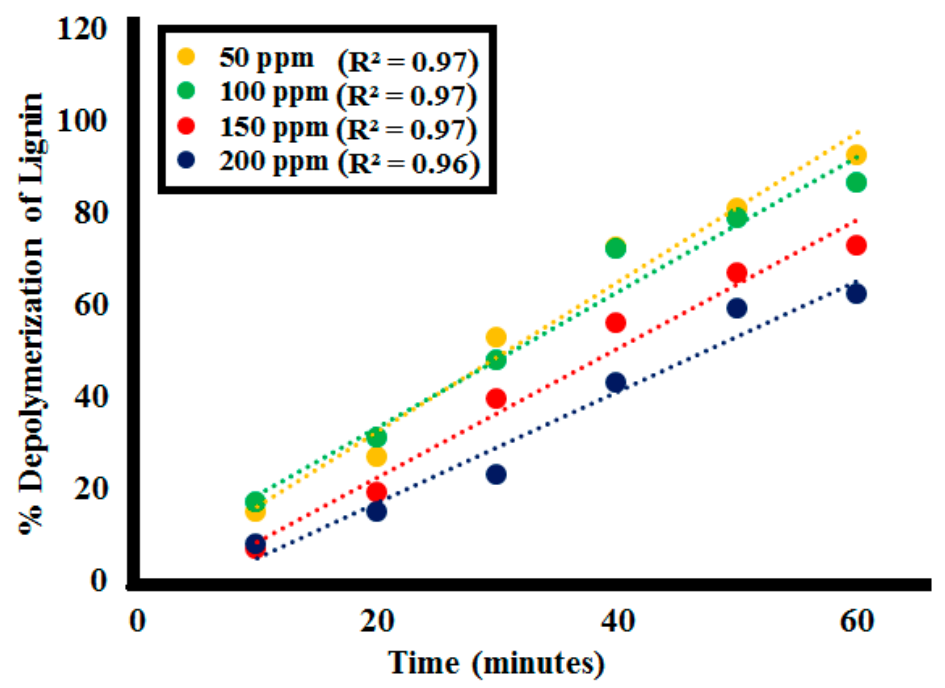

Figure 12. Correlation between \%lignin (L1) depolymerization of the different lignin concentrations by SK9 and the time intervals.

\subsubsection{Effect of Variating Temperature}

The dependence of rate constant of lignin depolymerization on temperature was investigated by $0.1 \mathrm{~g} \mathrm{SK9}$ (using $100 \mathrm{ppm}$ of L1) at 20,35, and 65 and $90^{\circ} \mathrm{C}$. After every $10 \mathrm{~min}$ interval of irradiation under UV light, a decrease in absorption intensity of the lignin solution was observed at each increase in temperature, as depicted in Figure 13 (detailed in Figure S3 of supplemental data). \%Lignin depolymerization was evaluated at different time intervals at each temperature. Depolymerization reaction rate along with \%lignin depolymerization tended to increase with the increasing range of temperature, as given in Table 5. Maximum \%depolymerization was obtained at $90{ }^{\circ} \mathrm{C}$ with $0.1 \mathrm{~g}$ SK9, which showed an increase in \%depolymerization with the increasing temperature. In total, $86.5 \%$ lignin depolymerization was calculated at room temperature $\left(20^{\circ} \mathrm{C}\right)$, whereas $89 \%$ for $35{ }^{\circ} \mathrm{C}, 92 \%$ for $65{ }^{\circ} \mathrm{C}$ and $97.5 \%$ for $90{ }^{\circ} \mathrm{C}$ temperature was achieved. The increase in \%depolymerization of lignin upon increasing temperature range was mainly because of the thermal breakdown of the aromatic backbone of the lignin crosslinked structure. Going to high temperatures caused the breakdown of crosslinked functionalities, resulting in depolymerization into monomeric compounds [57]. Correlation between \%lignin depolymerization by SK9 at various temperatures was calculated to be close 1, as given in Figure 14.

Table 5. \%Lignin $\left(\mathbf{L 1}_{100 \mathrm{ppm}}\right)$ depolymerization by SK9 $(0.1 \mathrm{~g})$ at the different temperatures and the time intervals.

\begin{tabular}{ccccc}
\hline Time & \multicolumn{4}{c}{ \%Lignin $\left(\mathbf{L 1}_{\mathbf{1 0 0 p p m}}\right)$ Depolymerization at Different Temperatures } \\
\hline $\mathbf{( m i n )}$ & $\mathbf{2 0}{ }^{\circ} \mathbf{C}$ & $\mathbf{3 5}{ }^{\circ} \mathbf{C}$ & $\mathbf{6 5}{ }^{\circ} \mathbf{C}$ & $\mathbf{9 0}{ }^{\circ} \mathbf{C}$ \\
\hline 0 & 0 & 0 & 0 & 0 \\
10 & 17 & 21 & 22 & 26.5 \\
20 & 31 & 26 & 27 & 31 \\
30 & 48 & 32 & 47 & 48 \\
40 & 72 & 50 & 64 & 69 \\
50 & 79 & 76.5 & 81 & 89 \\
60 & 86.5 & 89 & 92 & 97.5 \\
\hline
\end{tabular}




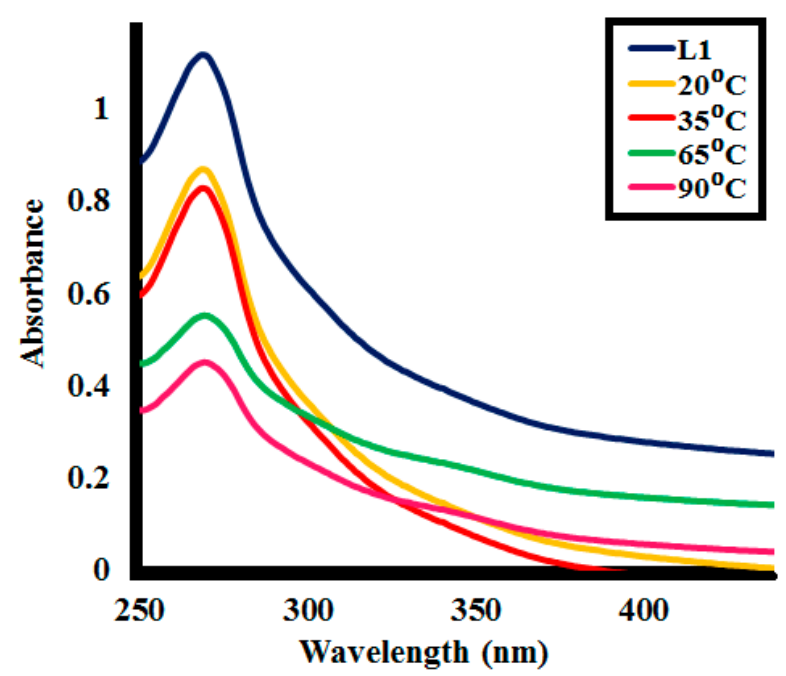

Figure 13. Photocatalytic lignin $\left(\mathbf{L 1}_{100 \mathrm{ppm}}\right)$ depolymerization by $0.1 \mathrm{~g}$ SK9 at the different temperatures after $60 \mathrm{~min}$ of catalytic activity.

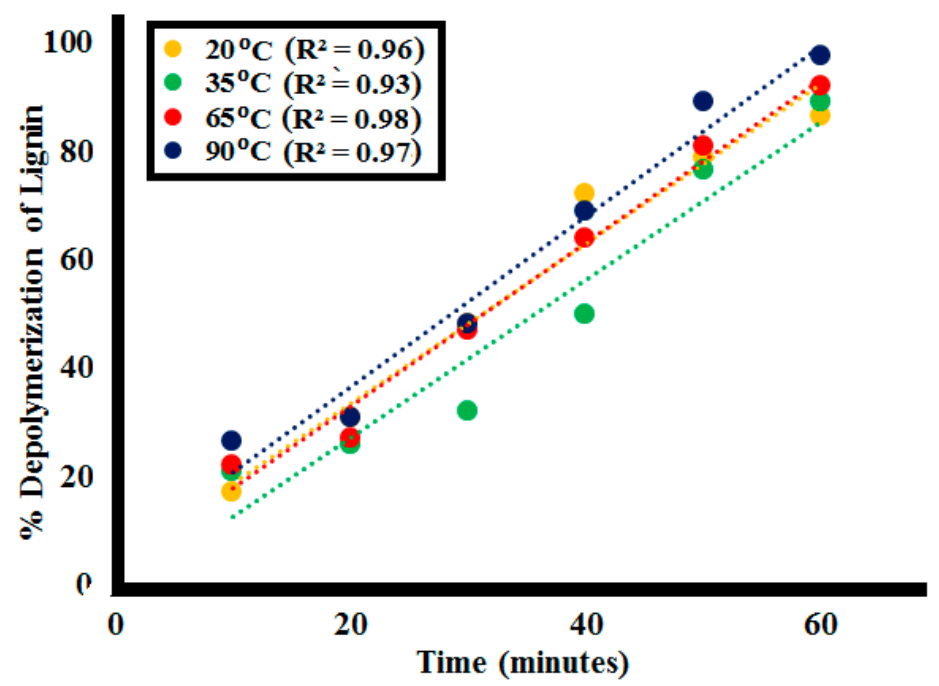

Figure 14. Correlation between \%depolymerization of the lignin $\left(\mathbf{L 1}_{100 \mathrm{ppm}}\right)$ by $\mathbf{S K 9}$ and different temperatures.

\subsection{Kinetic Analysis}

To determine adsorption kinetics of liquid/solid systems, pseudo kinetic models i.e., Pseudo-first order and pseudo-second order kinetics are often employed [58-60]. Kinetics of depolymerization of the lignin on the solid perovskite's surface was demonstrated best by the pseudo-second order kinetic model by following Equation (5):

$$
\mathrm{t} / \mathrm{C}_{\mathrm{t}}=1 / \mathrm{k}_{2} \mathrm{C}_{\mathrm{t}}^{2}+\mathrm{t} / \mathrm{C}_{\mathrm{o}}
$$

where $C_{t}$ is the concentration of the lignin solution at a specific time interval, $C_{o}$ is the initial lignin concentration, $\mathrm{t}$ is the time at which sample aliquot is taken and $\mathrm{k}$ is the rate constant at equilibrium for the pseudo-second order reaction. In the rate-controlling step, chemical reaction was found significant for all the factors studied. The $\mathrm{R}^{2}$ values at $0.025,0.05,0.075$, and $0.1 \mathrm{~g}$ catalyst $\mathrm{SK} 9$ doses calculated were around 1, as depicted in Figure 15. Meanwhile, $R^{2}$ values for 50, 100, 150, and 200 ppm lignin concentrations were also around 1, as shown in Figure 16. Pseudo-second order kinetics offered a significant correlation between the experimental data and the reaction mechanism was evaluated to be chemically rate-controlled [58]. 


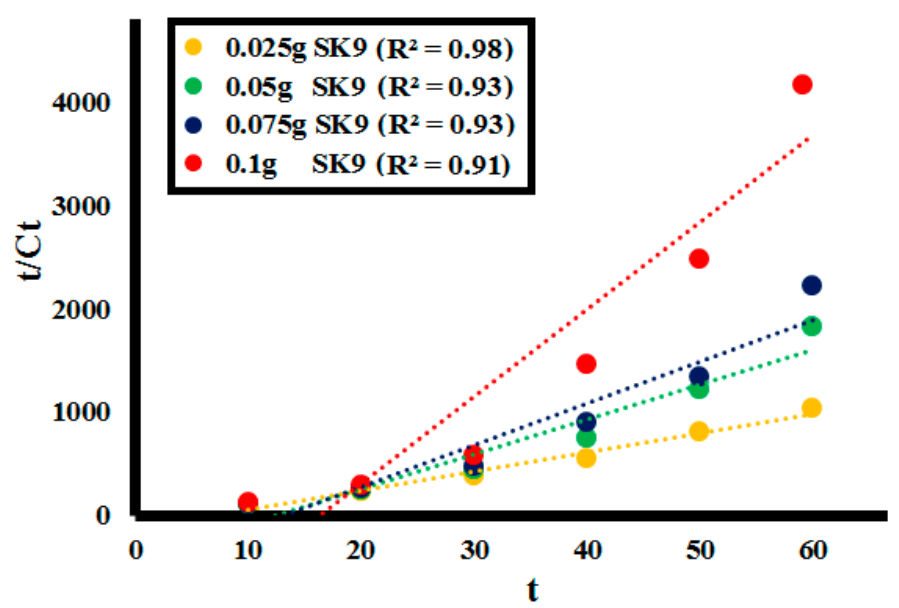

Figure 15. Pseudo-second order kinetics of the lignin $\left(\mathbf{L 1}_{100 \mathrm{ppm}}\right)$ depolymerization by different catalytic doses $(0.025-0.1 \mathrm{~g})$ of SK9.

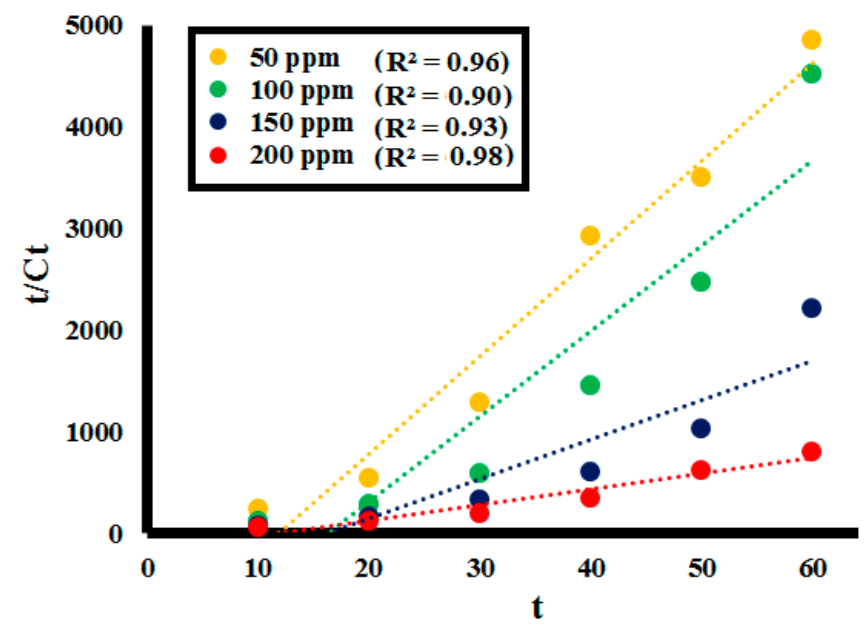

Figure 16. Pseudo-second order kinetics of the lignin $\left(\mathbf{L} \mathbf{1}_{100 \mathrm{ppm}}\right)$ depolymerization by different initial lignin concentrations (50-200 ppm).

\section{Activation Energy $\left(E_{a}\right)$}

During temperature treatment, the depolymerization stage is kinetically controlled by an energy barrier that encompasses multiple processes, like breaking of hydrogen bonds, water diffusion, and evaporation, among others [61]. Hence, activation energy values most probably depend upon the mechanistic clues of conversion, for example, the number of reaction steps involved in lignin depolymerization [62]. The pseudo-second order kinetic model was applied to data obtained during photo depolymerization of lignin with temperature variation and is depicted in Figure 17. It was observed that the depolymerization kinetic rate constant $(\mathrm{k})$ correspondingly increased with increasing temperature, as given in Table 6.

Table 6. Pseudo-second order kinetic parameters at different temperatures.

\begin{tabular}{ccc}
\hline \multicolumn{2}{c}{ Pseudo Second Order Kinetic Parameters at Different Temperatures } \\
\hline Temperature & Rate Constant $\mathbf{( k )}\left(\mathbf{g}^{\mathbf{- 1}} \mathbf{m i n}^{\mathbf{- 1}}\right)$ & $\mathbf{R}^{\mathbf{2}}$ \\
\hline $20^{\circ} \mathrm{C}$ & 0.011 & 0.97 \\
$35^{\circ} \mathrm{C}$ & 0.018 & 0.97 \\
$65^{\circ} \mathrm{C}$ & 0.132 & 0.98 \\
$90^{\circ} \mathrm{C}$ & 0.186 & 0.99 \\
\hline
\end{tabular}




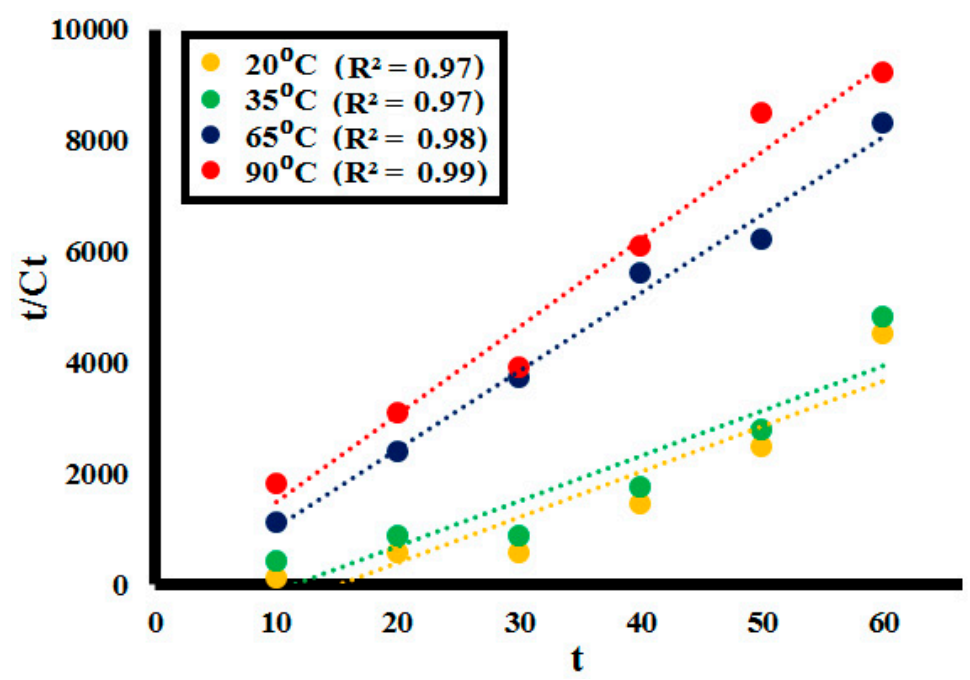

Figure 17. Pseudo-second order kinetics of the lignin depolymerization at different temperatures $\left(20-90^{\circ} \mathrm{C}\right)$.

By plotting the logarithm of apparent depolymerization kinetic constants (lnk) against 1/T, the linear curve was obtained, as depicted in Figure 18, with $0.97 R^{2}$ value following the Arrhenius equation $\left(\mathrm{k}=\mathrm{A}^{-\mathrm{Ea} / \mathrm{RT}}\right)$ rearrangement [63] as:

$$
\ln \mathrm{k}=-\mathrm{E}_{\mathrm{a}} / \mathrm{RT}+\ln \mathrm{A}
$$

where $\mathrm{k}$ is the reaction constant, $\mathrm{E}_{\mathrm{a}}$ is the activation energy $(\mathrm{kJ} / \mathrm{mol}), \mathrm{A}$ is the frequency factor $\left(\mathrm{h}^{-1}\right)$, $\mathrm{R}$ is the gas constant $(8.314 \mathrm{~J} / \mathrm{mol} \cdot \mathrm{K})$ and $\mathrm{T}$ is the temperature $(\mathrm{K})$. The $\mathrm{E}_{\mathrm{a}}$ for lignin depolymerization calculated from the slope of the line (Slope $=-E_{a} / R$ ) is $15 \mathrm{~kJ} / \mathrm{mol}$. Higher $E_{a}$ indicates the depolymerization reaction was less influenced by temperature according to the rule. The calculated activation energy was remarkably lower in comparison to conventional lignin depolymerization, i.e., $59.75 \mathrm{~kJ} / \mathrm{mol}$ [64]. Hence, a lower activation energy value signifies the efficiency of catalyst to depolymerize lignin more expediently.

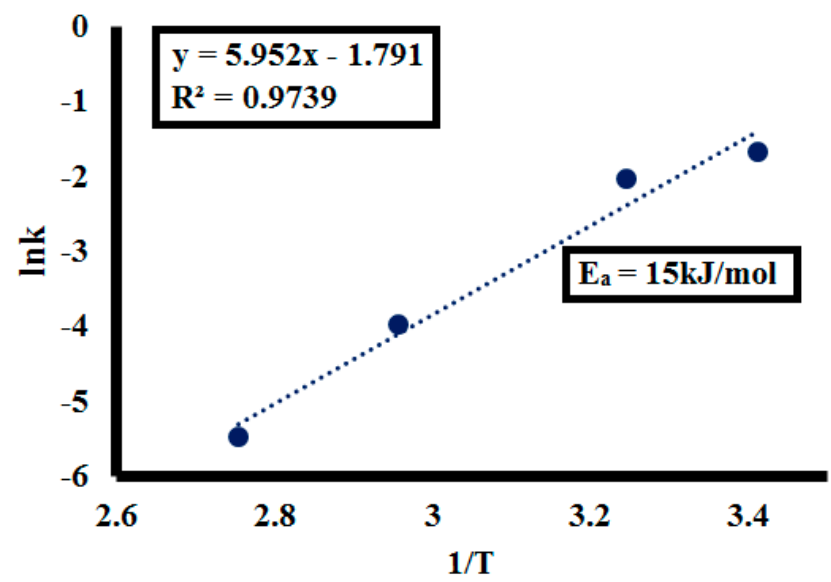

Figure 18. Arrhenius Law on temperature data.

\subsection{Characterization of Depolymerization Products}

GC-MS Analysis

The lignin depolymerization product (L1-SK9) was collected in liquid form after $60 \mathrm{~min}$ of photocatalytic activity of lignin (L1) with SK9 under UV light at room temperature $\left(20^{\circ} \mathrm{C}\right)$. The 
second product L1-SK9 $\left(90^{\circ} \mathrm{C}\right)$ was collected after $60 \mathrm{~min}$ of photocatalytic activity under the UV light of lignin by SK9 at $90^{\circ} \mathrm{C}$ to check the effect of higher temperature on lignin depolymerization. The GC is shown in Figure 19, which is characterized by the lignin solution peak before activity represented by ' $\mathbf{A}^{\prime}$ in the chromatogram. Different peaks of lignin depolymerization products (L1-SK9) and L1-SK9 $\left(90^{\circ} \mathrm{C}\right)$ represent the different monomeric lignin functionalities (listed in Table 7). MS corresponding to each GC signal is given in S4 section (supplemental data) with the structure of the expected compound present.

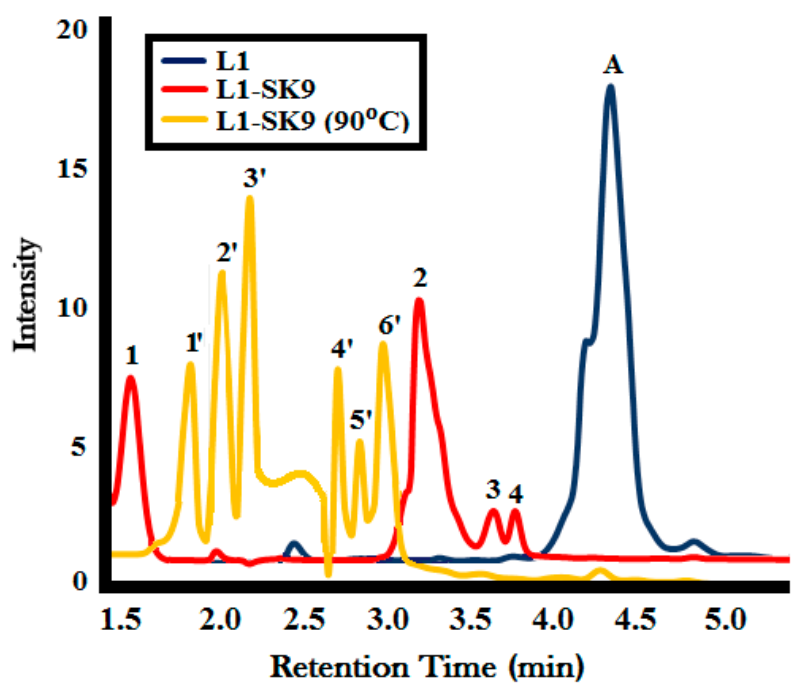

Figure 19. Gas spectrum (GC) of lignin (L1) and lignin depolymerization products L1-SK9 and L1-SK9 $\left(90^{\circ} \mathrm{C}\right)$; Samples after $60 \mathrm{~min}$ of photocatalytic activity under UV light at room temperature and at $90^{\circ} \mathrm{C}$, respectively.

Table 7. GC-MS data of the lignin depolymerization products L1-SK9 and L1-SK9 $\left(90{ }^{\circ} \mathrm{C}\right)$.

\begin{tabular}{|c|c|c|c|c|}
\hline $\begin{array}{l}\text { GC Peak } \\
\text { No. }\end{array}$ & $\begin{array}{l}\text { Retention Time } \\
\text { (RT) }\end{array}$ & $\begin{array}{l}m / z \text { of Molecular } \\
\text { Ion Peak }\end{array}$ & Name & $\begin{array}{c}\text { Concentration } \\
(\%)\end{array}$ \\
\hline \multicolumn{5}{|c|}{ L1-SK9 } \\
\hline 1 & 1.6 & 71 & Butadienol & 18 \\
\hline 2 & 3.1 & 137 & 2-methoxy-4-methylphenol & 39 \\
\hline 3 & 3.6 & 164 & 2-methoxy-5-propenyl phenol & 7 \\
\hline 4 & 3.8 & 244 & $\begin{array}{l}\text { 5-[2-(3-hydroxyphenyl)ethyl]-2-methoxyphenol } \\
\text { (guaiacyl dimer) }\end{array}$ & 6 \\
\hline \multicolumn{5}{|c|}{ L1-SK9 $\left(90^{\circ} \mathrm{C}\right)$} \\
\hline $\mathbf{1}^{\prime}$ & 1.9 & 75 & Methoxypropane & 14 \\
\hline $2^{\prime}$ & 2.1 & 78 & Benzene & 17 \\
\hline $3^{\prime}$ & 2.3 & 81 & Cyclohexene & 19 \\
\hline $4^{\prime}$ & 2.6 & 95 & Phenol & 10 \\
\hline $5^{\prime}$ & 2.8 & 110 & Catechol & 7 \\
\hline $6^{\prime}$ & 3.1 & 137 & 2-methoxy-4-methylphenol & 16 \\
\hline
\end{tabular}

In the depolymerization product of lignin (L1-SK9), peak $1(\mathrm{RT}=1.6)$ represents $18 \%$ butadienol $(m / z=71)$, which may be produced depolymerization of subunits between aromatic backbone of lignin $[65,66]$. Peak $2(\mathrm{RT}=3.1)$ and Peak $3(\mathrm{RT}=3.6)$ are attributed to 39\% of 2-methoxy-4-methylphenol $(\mathrm{m} / \mathrm{z}=137)$ and $7 \%$ 2-methoxy-5-propenyl phenol $(\mathrm{m} / \mathrm{z}=164)$, which are interlinking subunits in the lignin structure [67]. Peak $4(\mathrm{RT}=3.8)$ is due to $6 \%$ of 5-[2-(3-hydroxyphenyl)ethyl]-2-methoxyphenol $(m / z=244)$, which is basically the guaiacyl subunits of lignin structure [65]. On the other hand, in the depolymerization product of lignin L1-SK9 $\left(90^{\circ} \mathbf{C}\right)$, peak $\mathbf{1}^{\prime}(\mathrm{RT}=1.9)$ represents $14 \%$ methoxypropane $(m / z=75)$, which possibly originated due to further cracking of lignin interlinking subunits between the aromatic moieties due to temperature treatment. Peak $2^{\prime}(\mathrm{RT}=2.1)$ and peak $3^{\prime}(\mathrm{RT}=2.3)$ attributed to $17 \%$ of benzene $(m / z=78)$ and $19 \%$ cyclohexene $(m / z=81)$, whereas peak $4^{\prime}(R T=2.6)$ 
and peak $5^{\prime}(\mathrm{RT}=2.8)$ are due to $10 \%$ phenol $(\mathrm{m} / \mathrm{z}=95)$ and $7 \%$ catechol $(\mathrm{m} / \mathrm{z}=110)$, which are part of aromatic backbone of lignin structure along with 16\% 2-methoxy-4-methylphenol $(\mathrm{m} / \mathrm{z}=137$ at $\mathrm{RT}=3.1$ ) represented by peak $\mathbf{6}^{\prime}$. From the GC-MS analysis, it was indicated that temperature treatment assisted in increasing catalytic depolymerization of lignin structural subunits into small monomeric functionalities, which was in accordance with \%depolymerization obtained from temperature treatment during photocatalytic activity of lignin with SK9.

\section{Materials and Methods}

\subsection{Chemicals and Reagents}

Lignin was extracted from wood powder through the literature-reported organosolv acid treatment [68,69] reported in our recent study [70]. Lead chloride, $\mathrm{HCl}$, and iso-propyl amine were purchased from Sigma Aldrich (Saint Louis, MO, USA). All of the chemicals were of analytical grade and utilized without further purification.

Powder X-ray Diffraction (PXRD) analysis was carried out in an X-ray diffractometer (Bruker, AXS D8; Yokohama-shi, Japan) with Cu-K $\alpha$ radiation (1.54 $\AA$ ) in the $2 \theta$ range from $20^{\circ}$ to $60^{\circ}$. Scanning Electron Microscopy (SEM) (JEOL, JSM-6360 EO; Tokyo, Japan) analysis was performed to determine the morphological features of catalysts. Functional group characterization was done by an Infra-Red Spectrophotometer (Shimadzu; Osaka, Japan) in the range of wavenumber 500-4000 $\mathrm{cm}^{-1}$. Optical characterization was done by an Ultraviolet (UV) Spectrophotometer (Shimadzu; Osaka, Japan) in the frequency range of 250-800 nm and a Photoluminescence (PL) Spectrophotometer (Shimadzu; Osaka, Japan) at excitation wavelength $480 \mathrm{~nm}$. Catalytic depolymerization was studied by taking absorption spectra by an Ultraviolet (UV) Spectrophotometer (Shimadzu; Osaka, Japan) in the range of wavelength $250-800 \mathrm{~nm}$. Characterization of liquid lignin depolymerization products was done by Gas Chromatography Mass Spectrometry (GC-MS) (Shimadzu QP2010; Osaka, Japan, (MS Detector SPD 20A, Column: C-18 $(250 \times 4.6 \mathrm{~mm}))$, Temperature; $\left.300^{\circ} \mathrm{C}\right)$. A UV Lamp (length: $288 \mathrm{~mm}$, pipe diameter: $16 \mathrm{~mm}$, voltage: $220 \mathrm{~V}$, power: $8 \mathrm{~W}$, wavelength range: $240-285 \mathrm{~nm}$ ) was used as a light source for lignin depolymerization activity.

\subsection{Synthesis of iso-Propyl Amine Lead Chloride Perovskites ( $\mathrm{IAPbCl}_{3}$ ) (SK9-SK10)}

SK9 was prepared hydrothermally by taking $1 \mathrm{~g} \mathrm{PbCl}_{2}$ salt into a Teflon lined autoclave container. Then, $50 \% 10 \mathrm{~mL} \mathrm{HCl}$ and $4 \mathrm{~mL}$ iso-propyl amine (IA) were added. The container was tightly closed and heated at $150{ }^{\circ} \mathrm{C}$ for $24 \mathrm{~h}$. The shiny white crystals of the obtained material were filtered and air-dried. The SK9 obtained as white crystalline material which was characterized and used for catalytic activities. PXRD; D (77.19 \pm 5$)$. SK10 was synthesized following the same way as for SK9 by utilizing the $5 \mathrm{~mL}$ IA. The material SK10 was also obtained as white crystalline material, which was characterized and used for catalytic activities. PXRD; D (75.59 \pm 7$)$.

\subsection{Photocatalytic Activity under UV Light}

Photocatalytic depolymerization of the lignin was done according to our recently reported photocatalytic activity under sunlight [70] modifying the light source in current studies. Lignin was extracted from the wood powder of Oryza sativa through the organosolv acid treatment method discussed in detail in our recent work about lignin depolymerization [70].

For photocatalytic activity experiments, 100 ppm lignin (L1) solution was prepared in dioxane. In total, $50 \mathrm{~mL}$ of this solution was stirred under UV light irradiation with $0.1 \mathrm{~g}$ amount of catalysts (SK9 and SK10) separately. Aliquots of $5 \mathrm{~mL}$ from the reaction mixture were taken at time intervals of $10,20,30,40,50$, and 60 . A UV absorption spectrum was taken for all the taken aliquots at 
different time intervals. From the spectrum, the absorbance of samples at $280 \mathrm{~nm}$ was noted, and the \%depolymerization for all the sample aliquots was calculated by following Equation (7) [26].

$$
\% \text { Depolymerization }=\mathrm{C}_{\mathrm{o}}-\mathrm{C}_{\mathrm{t}} / \mathrm{C}_{\mathrm{o}} \times 100
$$

In the equation, $C_{0}$ is the starting concentration and $C_{t}$ is the concentration of samples at a specific time interval. The lignin concentration at certain time intervals was calculated by drawing the calibration curve between the known lignin concentration and absorbance. The unknown concentration of lignin for noted absorbance at the different time intervals was measured by the linear equation of the known data.

The calculation of kinetic parameters was done by varying the initial lignin concentrations (50, 100, 150 , and $200 \mathrm{ppm})$ and varying catalyst dosage $(0.025,0.05,0.075$ and $0.1 \mathrm{~g})$ at the different time intervals through the same method as explained above. Meanwhile, thermodynamic parameters were evaluated by varying the temperature range $\left(20,35,65,90^{\circ} \mathrm{C}\right)$ at different time intervals. Representative samples (L1-SK9, L1-SK9 (temperature treated)) after the photocatalytic lignin depolymerization activity were analyzed by GC-MS.

\section{Conclusions}

The presented work described the synthesis of two iso-propylamine-based lead chloride perovskite nanomaterials (SK9 and SK10) employed for photocatalytic applications. These perovskites were synthesized by employing a facile hydrothermal treatment and characterization was done by PXRD, SEM, UV, PL, and FTIR for determining the phase purity, structural composition, optical characteristics, and surface morphological features. Photocatalytic activity study was done by depolymerizing the lignin under UV light, which was extracted from the wood powder of Oryza sativa, reported in a previous work. Catalytic depolymerization of lignin by SK9 and SK10 was checked by absorption spectra at various time intervals and \%lignin depolymerization was calculated. The effect of increasing catalyst dosage, starting lignin concentrations, and varying temperature indicated a considerable increase in \%depolymerization of lignin. The kinetic study of investigated factors termed that pseudo-second order was the best suited kinetic model, with $\mathrm{R}^{2}>0.9$ representing that the reaction mechanism for lignin depolymerization was chemically controlled. The $\mathrm{E}_{\mathrm{a}}$ for the reaction was calculated to be $15 \mathrm{~kJ} / \mathrm{mol}$, which is much less than conventional depolymerization reactions, i.e., $59.75 \mathrm{~kJ} / \mathrm{mol}$, and shows the good catalytic proficiencies of perovskites to depolymerize the lignin. Depolymerization products of the lignin were characterized by GC-MS analysis. GC-MS analysis of the liquid product of the lignin depolymerization was obtained with SK9 at room temperature $\left(20{ }^{\circ} \mathrm{C}\right)$ and at $90{ }^{\circ} \mathrm{C}$, which indicated that temperature treatment assisted in increasing catalytic depolymerization of lignin structural subunits into small monomeric functionalities. Specifically, 39\% 2-methoxy-4-methylphenol, 17\% benzene, 10\% phenol, and 7\% catechol were confirmed by GC-MS analysis of lignin depolymerization.

Supplementary Materials: The following are available online at http://www.mdpi.com/1420-3049/25/15/3520/s1.

Author Contributions: Conceptualization, S.K. and A.A.A.; Methodology, S.K., M.H. (Mahwish Hadait) and A.A.; Investigation, S.K., A.A., N.R. and M.H. (Muhammad Hamayun); Resources, S.A.A.S., S.M. and A.B.; Writing-Original Draft Preparation, S.K., A.A.A. and A.A.; Writing-Review and Editing, A.A.A. and S.K.; Funding Acquisition, Z.A.Z. and A.A.A. All authors have read and agreed to the published version of the manuscript.

Funding: This research was mainly financially supported by Higher Education Commission Islamabad, Pakistan under HEC-NRPU project No. 6492.

Acknowledgments: Authors would also like to acknowledge the Ministry of Higher Education (MOHE) for financial support under the Fundamental Research Grant Scheme (FRGS) with sponsorship reference numbers FRGS/1/2019/STG05/UITM/02/9. The author would also like to acknowledge Universiti Teknologi MARA for the financial support under the reference number 600-IRMI/FRGS 5/3 (424/2019). The author from the King Khalid University, Saudi Arabia acknowledge the financial and technical support from Research Center for Advanced Material Science at King Khalid University through grant number RCAMS/KKU/014-20. 
Conflicts of Interest: Authors have no conflicts of interest.

\section{References}

1. Dapsens, P.Y.; Mondelli, C.; Pérez-Ramírez, J. Biobased Chemicals from Conception toward Industrial Reality: Lessons Learned and To Be Learned. ACS Catal. 2012, 2, 1487-1499. [CrossRef]

2. Huber, G.W.; Iborra, S.; Corma, A. Synthesis of transportation fuels from biomass: Chemistry, catalysts, and engineering. Chem. Rev. 2006, 106, 4044-4098. [CrossRef] [PubMed]

3. Luque, R.; Herrero-Davila, L.; Campelo, J.M.; Clark, J.H.; Hidalgo, J.M.; Luna, D.; Marinas, J.M.; Romero, A.A. Biofuels: A technological perspective. Energy Environ. Sci. 2008, 1, 542-564. [CrossRef]

4. Sheldon, R.A. Green and sustainable manufacture of chemicals from biomass: State of the art. Green Chem. 2014, 16, 950-963. [CrossRef]

5. Pérez, E.; Tuck, C.O.; Poliakoff, M. Valorisation of lignin by depolymerisation and fractionation using supercritical fluids and conventional solvents. J. Supercrit. Fluids 2018, 133, 690-695. [CrossRef]

6. Ragauskas, A.J.; Beckham, G.T.; Biddy, M.; Chandra, R.; Chen, F.; Davis, M.F.; Davison, B.H.; Dixon, R.A.; Gilna, P.; Keller, M.; et al. Lignin Valorization: Improving Lignin Processing in the Biorefinery. Science 2014, 344, 1246843. [CrossRef] [PubMed]

7. Zakzeski, J.; Bruijnincx, P.C.A.; Jongerius, A.L.; Weckhuysen, B.M. The Catalytic Valorization of Lignin for the Production of Renewable Chemicals. Chem. Rev. 2010, 110, 3552-3599. [CrossRef] [PubMed]

8. Calvo-Flores, F.G.; Dobado, J.A. Lignin as Renewable Raw Material. ChemSusChem 2010, 3, $1227-1235$. [CrossRef]

9. Ma, R.; Xu, Y.; Zhang, X. ChemInform Abstract: Catalytic Oxidation of Biorefinery Lignin to Value-Added Chemicals to Support Sustainable Biofuel Production. Cheminform 2015, 46, 24-51. [CrossRef]

10. Lavoie, J.-M.; Baré, W.; Bilodeau, M. Depolymerization of steam-treated lignin for the production of green chemicals. Bioresour. Technol. 2011, 102, 4917-4920. [CrossRef]

11. Grabber, J.H. How Do Lignin Composition, Structure, and Cross-Linking Affect Degradability? A Review of Cell Wall Model Studies. Crop. Sci. 2005, 45, 820-831. [CrossRef]

12. Deuss, P.J.; Barta, K.; De Vries, J.G. Homogeneous catalysis for the conversion of biomass and biomass-derived platform chemicals. Catal. Sci. Technol. 2014, 4, 1174-1196. [CrossRef]

13. Deuss, P.J.; Barta, K. From models to lignin: Transition metal catalysis for selective bond cleavage reactions. Coord. Chem. Rev. 2016, 306, 510-532. [CrossRef]

14. Li, C.; Zhao, X.; Wang, A.; Huber, G.W.; Zhang, T. Catalytic Transformation of Lignin for the Production of Chemicals and Fuels. Chem. Rev. 2015, 115, 11559-11624. [CrossRef]

15. Kobayashi, H.; Ohta, H.; Fukuoka, A. Conversion of lignocellulose into renewable chemicals by heterogeneous catalysis. Catal. Sci. Technol. 2012, 2, 869-883. [CrossRef]

16. Liu, W.-J.; Jiang, H.; Yu, H.-Q. Thermochemical conversion of lignin to functional materials: A review and future directions. Green Chem. 2015, 17, 4888-4907. [CrossRef]

17. Abdelaziz, O.Y.; Brink, D.P.; Prothmann, J.; Ravi, K.; Sun, M.; García-Hidalgo, J.; Sandahl, M.; Hulteberg, C.P.; Turner, C.; Lidén, G.; et al. Biological valorization of low molecular weight lignin. Biotechnol. Adv. 2016, 34, 1318-1346. [CrossRef]

18. Sun, Z.-H.; Fridrich, B.; De Santi, A.; Elangovan, S.; Barta, K. Bright Side of Lignin Depolymerization: Toward New Platform Chemicals. Chem. Rev. 2018, 118, 614-678. [CrossRef]

19. Strieth-Kalthoff, F.; James, M.; Teders, M.; Pitzer, L.; Glorius, F. Energy transfer catalysis mediated by visible light: Principles, applications, directions. Chem. Soc. Rev. 2018, 47, 7190-7202. [CrossRef]

20. Romero, N.A.; Nicewicz, D.A. Organic Photoredox Catalysis. Chem. Rev. 2016, 116, 10075-10166. [CrossRef]

21. Ravelli, D.; Protti, S.; Fagnoni, M. Carbon-Carbon Bond Forming Reactions via Photogenerated Intermediates. Chem. Rev. 2016, 116, 9850-9913. [CrossRef] [PubMed]

22. Pandey, K.K. Study of the effect of photo-irradiation on the surface chemistry of wood. Polym. Degrad. Stab. 2005, 90, 9-20. [CrossRef]

23. Uğurlu, M.; Karaoğlu, M.H. Removal of AOX, total nitrogen and chlorinated lignin from bleached Kraft mill effluents by UV oxidation in the presence of hydrogen peroxide utilizing $\mathrm{TiO}_{2}$ as photocatalyst. Environ. Sci. Pollut. Res. 2008, 16, 265-273. [CrossRef] [PubMed] 
24. Li, S.-H.; Liu, S.; Colmenares, J.C.; Xu, Y.-J. A sustainable approach for lignin valorization by heterogeneous photocatalysis. Green Chem. 2016, 18, 594-607. [CrossRef]

25. Colmenares, J.C.; Varma, R.S.; Nair, V. Selective photocatalysis of lignin-inspired chemicals by integrating hybrid nanocatalysis in microfluidic reactors. Chem. Soc. Rev. 2017, 46, 6675-6686. [CrossRef]

26. Sheldon, R.A. Engineering a more sustainable world through catalysis and green chemistry. J. R. Soc. Interface 2016, 13, 20160087. [CrossRef]

27. Ma, Y.-S.; Chang, C.-N.; Chiang, Y.-P.; Sung, H.-F.; Chao, A.C. Photocatalytic degradation of lignin using $\mathrm{Pt} / \mathrm{TiO}_{2}$ as the catalyst. Chemosphere 2008, 71, 998-1004. [CrossRef]

28. Wu, W.-B.; Wong, Y.-C.; Tan, Z.-K.; Wu, J. Photo-induced thiol coupling and C-H activation using nanocrystalline lead-halide perovskite catalysts. Catal. Sci. Technol. 2018, 8, 4257-4263. [CrossRef]

29. Snaith, H.J. Present status and future prospects of perovskite photovoltaics. Nat. Mater. 2018, 17, $372-376$. [CrossRef]

30. Xu, J.; Huang, W.; Li, P.; Onken, D.R.; Dun, C.; Guo, Y.; Ucer, K.B.; Lu, C.; Wang, H.; Geyer, S.M.; et al. Imbedded Nanocrystals of $\mathrm{CsPbBr}_{3}$ in $\mathrm{Cs}_{4} \mathrm{PbBr}_{6}$ : Kinetics, Enhanced Oscillator Strength, and Application in Light-Emitting Diodes. Adv. Mater. 2017, 29, 1703703. [CrossRef]

31. Wei, H.; Fang, Y.; Mulligan, P.L.; Chuirazzi, W.; Fang, H.-H.; Wang, C.; Ecker, B.; Gao, Y.; Loi, M.A.; Cao, L.; et al. Sensitive $\mathrm{X}$-ray detectors made of methylammonium lead tribromide perovskite single crystals. Nat. Photon. 2016, 10, 333-339. [CrossRef]

32. Tiep, N.H.; Ku, Z.; Fan, H.J. Recent Advances in Improving the Stability of Perovskite Solar Cells. Adv. Energy Mater. 2015, 6, 1501420. [CrossRef]

33. Chen, Q.; De Marco, N.; Song, T.-B.; Chen, C.-C.; Zhao, H.; Hong, Z.; Zhou, H.; Yang, Y. (Michael); Yang, Y. Under the spotlight: The organic-inorganic hybrid halide perovskite for optoelectronic applications. Nano Today 2015, 10, 355-396. [CrossRef]

34. Stranks, S.D.; Eperon, G.E.; Grancini, G.; Menelaou, C.; Alcocer, M.; Leijtens, T.; Herz, L.M.; Petrozza, A.; Snaith, H.J. Electron-Hole Diffusion Lengths Exceeding 1 Micrometer in an Organometal Trihalide Perovskite Absorber. Science 2013, 342, 341-344. [CrossRef] [PubMed]

35. Xing, G.; Mathews, N.; Sun, S.; Lim, S.S.; Lam, Y.M.; Grätzel, M.; Mhaisalkar, S.G.; Sum, T.C. Long-Range Balanced Electron- and Hole-Transport Lengths in Organic-Inorganic $\mathrm{CH}_{3} \mathrm{NH}_{3} \mathrm{PbI}_{3}$. Science 2013, 342, 344-347. [CrossRef] [PubMed]

36. Liu, Y.; Yang, Z.; Cui, D.; Ren, X.; Sun, J.; Liu, X.; Zhang, J.; Wei, Q.; Fan, H.; Yucheng, L.; et al. Two-Inch-Sized Perovskite $\mathrm{CH}_{3} \mathrm{NH}_{3} \mathrm{PbX}_{3}(\mathrm{X}=\mathrm{Cl}, \mathrm{Br}$, I) Crystals: Growth and Characterization. Adv. Mater. 2015, 27, 5176-5183. [CrossRef]

37. Riente, P.; Noël, T.; Paiva, P.R. Application of metal oxide semiconductors in light-driven organic transformations. Catal. Sci. Technol. 2019, 9, 5186-5232. [CrossRef]

38. Yahya, N.; Nasir, A.M.; Daub, N.A.; Aziz, F.; Aizat, A.; Jaafar, J.; Lau, W.J.; Yusof, N.; Salleh, W.N.W.; Ismail, A.F.; et al. Visible Light-Driven Perovskite-Based Photocatalyst for Wastewater Treatment; Elsevier BV: Amsterdam, The Netherlands, 2020; pp. 265-302.

39. Luciani, G.; Imparato, C.; Vitiello, G. Photosensitive Hybrid Nanostructured Materials: The Big Challenges for Sunlight Capture. Catalysts 2020, 10, 103. [CrossRef]

40. Fu, Y.; Meng, F.; Rowley, M.B.; Thompson, B.J.; Shearer, M.J.; Ma, D.; Hamers, R.J.; Wright, J.C.; Jin, S. Solution Growth of Single Crystal Methylammonium Lead Halide Perovskite Nanostructures for Optoelectronic and Photovoltaic Applications. J. Am. Chem. Soc. 2015, 137, 5810-5818. [CrossRef]

41. Mashiyama, H.; Kawamura, Y.; Magoma, E.; Kubota, Y. Displacive character of the cubic-tetragonal transition in $\mathrm{CH}_{3} \mathrm{NH}_{3} \mathrm{PbX}_{3}$. J. Korean Phys. Soc. 2003, 42, S1026-S1029.

42. Edri, E.; Kirmayer, S.; Kulbak, M.; Hodes, G.; Cahen, D. Chloride Inclusion and Hole Transport Material Doping to Improve Methyl Ammonium Lead Bromide Perovskite-Based High Open-Circuit Voltage Solar Cells. J. Phys. Chem. Lett. 2014, 5, 429-433. [CrossRef] [PubMed]

43. Jagodzinski, H. The Role of Munich in X-Ray Crystallography and the Development of Powder Diffraction. Mater. Sci. Forum 1991, 79, 1-16. [CrossRef]

44. Cullity, B.; Stock, S. Elements of X-Ray Diffraction, 3rd ed.; Prentice Hall: New York, NY, USA, 2001; pp. $174-177$.

45. Saleem, M. Effect of zinc acetate concentration on the structural and optical properties of ZnO thin films deposited by Sol-Gel method. Int. J. Phys. Sci. 2012, 7, 2971-2979. [CrossRef] 
46. Aé, L.; Kieven, D.; Chen, J.; Klenk, R.; Rissom, T.; Tang, Y.; Lux-Steiner, M.C.; Rissom, T. ZnO nanorod arrays as an antireflective coating for $\mathrm{Cu}(\mathrm{In}, \mathrm{Ga}) \mathrm{Se}_{2}$ thin film solar cells. Prog. Photovolt. Res. Appl. 2010, 18, $209-213$. [CrossRef]

47. Bindu, P.; Thomas, S. Estimation of lattice strain in $\mathrm{ZnO}$ nanoparticles: X-ray peak profile analysis. J. Theor. Appl. Phys. 2014, 8, 123-134. [CrossRef]

48. Kanemitsu, Y. Luminescence spectroscopy of lead-halide perovskites: Materials properties and application as photovoltaic devices. J. Mater. Chem. C 2017, 5, 3427-3437. [CrossRef]

49. Sarkar, P.; Mazumder, J.; Tripathy, S.K.; Baishnab, K.L.; Palai, G. Structural, optoelectronic, and morphological study of indium-doped methylammonium lead chloride perovskites. Appl. Phys. A 2019, 125, 580. [CrossRef]

50. De Matteis, F.; Vitale, F.; Privitera, S.; Ciotta, E.; Pizzoferrato, R.; Generosi, A.; Paci, B.; Di Mario, L.; Cresi, J.S.P.; Martelli, F.; et al. Optical Characterization of Cesium Lead Bromide Perovskites. Catalysts 2019, 9, 280. [CrossRef]

51. Labhsetwar, N.K.; Watanabe, A.; Mitsuhashi, T. New improved syntheses of LaRuO3 perovskites and their applications in environmental catalysis. Appl. Catal. B Environ. 2003, 40, 21-30. [CrossRef]

52. Zhu, J.; Li, H.; Zhong, L.; Xiao, P.; Xu, X.; Yang, X.; Zhao, Z.; Li, J. Perovskite Oxides: Preparation, Characterizations, and Applications in Heterogeneous Catalysis. ACS Catal. 2014, 4, 2917-2940. [CrossRef]

53. Tombe, S.; Adam, G.; Heilbrunner, H.; Apaydin, D.H.; Ulbricht, C.; Sariciftci, N.S.; Arendse, C.J.; Iwuoha, E.I.; Scharber, M.C. Optical and electronic properties of mixed halide $(\mathrm{X}=\mathrm{I}, \mathrm{Cl}, \mathrm{Br})$ methylammonium lead perovskite solar cells. J. Mater. Chem. C 2017, 5, 1714-1723. [CrossRef]

54. Park, B.-W.; Philippe, B.; Jain, S.M.; Zhang, X.; Edvinsson, T.; Rensmo, H.; Zietz, B.; Boschloo, G. Chemical engineering of methylammonium lead iodide/bromide perovskites: Tuning of opto-electronic properties and photovoltaic performance. J. Mater. Chem. A 2015, 3, 21760-21771. [CrossRef]

55. Kostka, P.; Lezal, D.; Poulain, M.; Pedlíková, J.; Novotna, M. Glass Formation in the $\mathrm{PbCl}_{2}-\mathrm{Sb}_{2} \mathrm{O}_{3}-\mathrm{TeO}_{2}$ System. Solid State Phenom. 2003, 235-240. [CrossRef]

56. Zhao, J.; Xiuwen, W.; Hu, J.; Liu, Q.; Shen, D.; Xiao, R. Thermal degradation of softwood lignin and hardwood lignin by TG-FTIR and Py-GC/MS. Polym. Degrad. Stab. 2014, 108, 133-138. [CrossRef]

57. Sharma, R.; Wooten, J.B.; Baliga, V.L.; Lin, X.; Chan, W.G.; Hajaligol, M.R. Characterization of chars from pyrolysis of lignin. Fuel 2004, 83, 1469-1482. [CrossRef]

58. Ho, Y.; McKay, G. Pseudo-second order model for sorption processes. Process. Biochem. 1999, 34, 451-465. [CrossRef]

59. Ho, Y.; McKay, G. Kinetic Models for the Sorption of Dye from Aqueous Solution by Wood. Process. Saf. Environ. Prot. 1998, 76, 183-191. [CrossRef]

60. Liu, Z.; Zhang, F.-S. Removal of lead from water using biochars prepared from hydrothermal liquefaction of biomass. J. Hazard. Mater. 2009, 167, 933-939. [CrossRef]

61. Várhegyi, G.; Antal, M.J.; Jakab, E.; Szabó, P. Kinetic modeling of biomass pyrolysis. J. Anal. Appl. Pyrolysis 1997, 42, 73-87. [CrossRef]

62. Carrier, M.; Auret, L.; Bridgwater, T.; Knoetze, J.H. Using Apparent Activation Energy as a Reactivity Criterion for Biomass Pyrolysis. Energy Fuels 2016, 30, 7834-7841. [CrossRef]

63. Bu, Q.; Lei, H.; Qian, M.; Yadavalli, G. A thermal behavior and kinetics study of the catalytic pyrolysis of lignin. RSC Adv. 2016, 6, 100700-100707. [CrossRef]

64. Damayanti; Wu, H.-S. Pyrolysis kinetic of alkaline and dealkaline lignin using catalyst. J. Polym. Res. 2017, 25, 7. [CrossRef]

65. Saito, K.; Kato, T.; Takamori, H.; Kishimoto, T.; Fukushima, K. A New Analysis of the Depolymerized Fragments of Lignin Polymer Using ToF-SIMS. Biomacromolecules 2005, 6, 2688-2696. [CrossRef] [PubMed]

66. Miller, J.; Evans, L.; Littlewolf, A.; Trudell, D. Batch microreactor studies of lignin and lignin model compound depolymerization by bases in alcohol solvents. Fuel 1999, 78, 1363-1366. [CrossRef]

67. Ohra-Aho, T.; Tenkanen, M.; Tamminen, T. Direct analysis of lignin and lignin-like components from softwood kraft pulp by Py-GC/MS techniques. J. Anal. Appl. Pyrolysis 2005, 74, 123-128. [CrossRef]

68. Pecina, R.; Burtscher, P.; Bonn, G.; Bobleter, O. GC-MS and HPLC analyses of lignin degradation products in biomass hydrolyzates. Anal. Bioanal. Chem. 1986, 325, 461-465. [CrossRef]

69. Watkins, D.; Nuruddin, M.; Hosur, M.; Tcherbi-Narteh, A.; Jeelani, S. Extraction and characterization of lignin from different biomass resources. J. Mater. Res. Technol. 2015, 4, 26-32. [CrossRef] 
70. Kausar, S.; Altaf, A.A.; Hamayun, M.; Danish, M.; Zubair, M.; Naz, S.; Muhammad, S.; Zaheer, M.; Ullah, S.; Badshah, A. Soft template-based bismuth doped zinc oxide nanocomposites for photocatalytic depolymerization of lignin. Inorg. Chim. Acta 2020, 502, 119390. [CrossRef]

Sample Availability: Samples of the compounds are available from the authors.

(C) 2020 by the authors. Licensee MDPI, Basel, Switzerland. This article is an open access article distributed under the terms and conditions of the Creative Commons Attribution (CC BY) license (http://creativecommons.org/licenses/by/4.0/). 